\title{
Injection in the lower stratosphere of biomass fire emissions followed by long-range transport: a MOZAIC case study
}

\author{
J.-P. Cammas ${ }^{1}$, J. Brioude ${ }^{2}$, J.-P. Chaboureau ${ }^{1}$, J. Duron ${ }^{1}$, C. Mari ${ }^{1}$, P. Mascart ${ }^{1}$, P. Nédélec ${ }^{1}$, H. Smit ${ }^{3}$, H.-W. Pätz ${ }^{3}$, \\ A. Volz-Thomas ${ }^{3}$, A. Stohl ${ }^{4}$, and M. Fromm ${ }^{5}$ \\ ${ }^{1}$ Université de Toulouse, UPS, LA (Laboratoire d'Aérologie), 14 avenue Edouard Belin, 31400 Toulouse, France and CNRS, \\ LA (Laboratoire d'Aérologie), 31400 Toulouse, France \\ ${ }^{2}$ Chemical Sciences Division, Earth Science Research Laboaratory, NOAA, Boulder, Colorado, USA \\ ${ }^{3}$ Forschungszentrum, Jülich, Germany \\ ${ }^{4}$ Norwegian Institute for Air Research (NILU), Kjeller, Norway \\ ${ }^{5}$ Naval Research Laboratory, Washington DC, USA
}

Received: 20 August 2008 - Published in Atmos. Chem. Phys. Discuss.: 16 December 2008

Revised: 4 August 2009 - Accepted: 10 August 2009 - Published: 12 August 2009

\begin{abstract}
This paper analyses a stratospheric injection by deep convection of biomass fire emissions over North America (Alaska, Yukon and Northwest Territories) on 24 June 2004 and its long-range transport over the eastern coast of the United States and the eastern Atlantic. The case study is based on airborne MOZAIC observations of ozone, carbon monoxide, nitrogen oxides and water vapour during the crossing of the southernmost tip of an upper level trough over the Eastern Atlantic on 30 June and on a vertical profile over Washington DC on 30 June, and on lidar observations of aerosol backscattering at Madison (University of Wisconsin) on 28 June. Attribution of the observed CO plumes to the boreal fires is achieved by backward simulations with a Lagrangian particle dispersion model (FLEXPART). A simulation with the Meso-NH model for the source region shows that a boundary layer tracer, mimicking the boreal forest fire smoke, is lofted into the lowermost stratosphere $(2-5 \mathrm{pvu}$ layer) during the diurnal convective cycle at isentropic levels (above $335 \mathrm{~K}$ ) corresponding to those of the downstream MOZAIC observations. It is shown that the order of magnitude of the time needed by the parameterized convective detrainment flux to fill the volume of a model mesh $(20 \mathrm{~km}$ horizontal, $500 \mathrm{~m}$ vertical) above the tropopause with pure boundary layer air would be about $7.5 \mathrm{~h}$, i.e. a time period compatible with the convective diurnal cycle. Over the area of interest, the maximum instantaneous detrainment fluxes deposited about 15 to $20 \%$ of the initial boundary layer
\end{abstract}

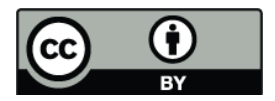

Correspondence to: J.-P. Cammas (jean-pierre.cammas@aero.obs-mip.fr) tracer concentration at $335 \mathrm{~K}$. According to the 275-ppbv carbon monoxide maximum mixing ratio observed by MOZAIC over Eastern Atlantic, such detrainment fluxes would be associated with a 1.4-1.8 ppmv carbon monoxide mixing ratio in the boundary layer over the source region.

\section{Introduction}

Biomass burning is a major source of trace gases for the global atmosphere (Crutzen and Andreae, 1990). Although biomass burning is thought to predominantly occur in the tropics, fires are also common in the boreal zone (Lavoué et al., 2000). However, only little is known about their atmospheric impact (Wotawa and Trainer, 2000). Smoke emissions represent large perturbations to the regional radiative budget (Robock, 1991 ; Iacobellis et al., 1999; Petzold et al., 2007) and indirectly influence cloud processes. Boreal fires might account for as much as $25 \%$ of the global CO emissions from all fires during anomalous boreal fire years (Goode et al., 2000; Lavoué et al., 2000). Chemistry in the fire plumes may lead to formation of tropospheric ozone (Crutzen and Andreae, 1990; Forster et al., 2001), which may exert a significant climate forcing in downwind regions. However, fire plumes with a negative $\mathrm{O}_{3}-\mathrm{CO}$ correlation have also been observed, e.g. Real et al. (2008) during the ICARTT campaign. When transported to lower altitudes, boreal fire emissions contribute to poor air quality and exacerbate pre-existing air quality problems (Wotawa and Trainer, 2000; Forster et al., 2001; Jaffe et al., 2004; Bertschi and Jaffe, 2005). The convection enhanced by the strong forest

Published by Copernicus Publications on behalf of the European Geosciences Union. 
fire activity, i.e. the so-called pyro-convection, can inject fire emissions to the upper troposphere and lower stratosphere (UTLS) (Waibel et al., 1999; Fromm et al., 2000; Fromm and Servranckx, 2003; Jost et al., 2004; Fromm et al., 2005; Nédélec et al., 2005; Damoah et al., 2006) with possibly longlasting implications for radiation and for stratospheric chemistry.

Modeling studies (Luderer et al., 2006; Trentmann et al., 2006) identified the background meteorology and the fire heating as the most important contributing factors for biomass burning injection into the lower stratosphere. Whereas the initialization with a cold front profile resulted in substantial stratospheric injection of biomass burning emissions, the injection was much weaker for the initialization with pre- and post-front profiles. The model results also suggested that the greater input of sensible heat release by the fires being the most important parameter influencing the pyro-convection, giving rise to a positive feedback with the latent heat release. Small-scale mixing processes enhanced by gravity waves, induced by the overshooting convection, increase the irreversible transport of forest fire emissions into the lower stratosphere (Luderer et al., 2007). There the residence times could be long enough to have a significant impact on the chemistry.

Hence, assessing the effect of boreal fire emissions on the UTLS composition on a global scale is challenging. Additional studies of other events are required to better document the contributions of biomass burning on the composition of the UTLS, as well as assess our modeling capacity in a variety of atmospheric conditions and fire activities. According to van der Werf et al. (2006) and to Damoah et al. (2006), the boreal fire activity over Alaska, Yukon and Northwest Territories was very strong in summer 2004. The area burned that year was the highest on record to date. The pollutants emitted from the fires led to violation of federal standards for air quality in Alaska. Real et al. (2007) describe the processes influencing $\mathrm{O}_{3}$ levels in Alaskan forest fire plumes in 2004 from measurements in several biomass burning plumes over Europe and show that $\mathrm{O}_{3}$ impact of Alaskan fires can be potentially significant over Europe. Pfister et al. (2006) show that on average the fires increased the $\mathrm{O}_{3}$ burden (surface $300 \mathrm{hPa}$ ) over Alaska and Canada during summer 2004 by about $7-9 \%$ and over Europe by about $2-3 \%$.

We report on MOZAIC observations (Measurements of OZone, water vapour, carbon monoxide and nitrogen oxides by Airbus In-sercice airCraft, Marenco et al., 1998, http: //mozaic.aero.obs-mip.fr/web/) made by airliners at cruise altitudes (10-11 km altitude) over the Eastern Atlantic and during a vertical profile over Washington, DC (USA) on June 30th 2004. The goals of the study are to (i) attribute anomalous CO mixing ratios in MOZAIC observations to boreal fire emissions over North America using a Lagrangian dispersion particle model, (ii) evaluate the capacity of a mesoscale model simulation with parameterized convection to vertically transport biomass-fire like emissions over the fire region up to isentropic levels corresponding to MOZAIC observations, (iii) further evaluate the mesoscale model simulation by assessing the $\mathrm{CO}$ mixing ratio in biomass fire emissions and comparing it to reported observations in the literature.

\section{Data and model descriptions}

\subsection{Measurement data}

Measurements of ozone in the MOZAIC program are taken every four seconds from take-off to landing. Based on the dual-beam UV absorption principle (Model 49-103, Thermo Environment Instruments, USA), the measurement accuracy is estimated at $\pm[2 \mathrm{ppbv}+2 \%]$ (Thouret et al., 1998). From the beginning of the program in 1994, the measurement quality control procedures have remained unchanged to ensure that long-term series are free of instrumental artifacts. Instruments are calibrated in the laboratory before and after the flight periods, whose duration is generally 12 months. The laboratory calibration is performed with a reference analyser which is periodically cross-checked with a primary standard at the National Institute of Standards and Technology in France. Additionally, each intrument's zero and calibration factor are regularly checked in-flight, using a built-in ozone generator. $\mathrm{CO}$ measurements are performed using an improved infrared correlation instrument, with a $30 \mathrm{~s} \mathrm{time}$ resolution (corresponding to a travel distance of $7.5 \mathrm{~km}$ at cruise altitude) and a precision of $\pm[5 \mathrm{ppbv}+5 \%]$. Details on the measurement technique can be found in Nédélec et al. (2003). A special airborne humidity sensing device is used for measuring relative humidity and temperature of the atmosphere (Helten et al., 1998, 1999). Measurements of total odd nitrogen $\left(\mathrm{NO}_{\mathrm{y}}=\mathrm{NO}+\mathrm{NO}_{2}+\mathrm{HNO}_{3}+P A N\right.$, with $P A N$ being peroxyacetylnitrate) are made aboard one MOZAIC aircraft using the chemiluminescence analyzer with gold converter described in Volz-Thomas et al. (2005). The instrument is automatically calibrated in flight with an NO calibration gas and the conversion efficiency of the converter is determined with $\mathrm{NO}_{2}$ produced in-situ by gas phase titration. The instrument is replaced and serviced every 4-6 weeks. Calibrations in the laboratory include also the conversion of $\mathrm{HNO}_{3}$. A comparison between the MOZAIC instrument with a research instrument using as well a gold converter and chemiluminescence as measurement principles (ECO-Physics instrument) is described in Pätz et al. (2006). Unfortunately, the $\mathrm{NO}_{\mathrm{y}}$ instrument was likely not detecting $\mathrm{HNO}_{3}$ during the period of concern. Although the conversion efficiency for $\mathrm{NO}_{2}$ was always $>95 \%$ during the entire deployment period, the atmospheric $\mathrm{NO}_{\mathrm{y}}$ concentrations were much lower than observed otherwise in MOZAIC and what has been observed by other authors, e.g. Murphy and Fahey (1994). The usually observed correlation between $\mathrm{NO}_{\mathrm{y}}$ and ozone in the lower stratosphere was almost absent. The data presented below are thus likely resembling the concentration of 
$\left(\mathrm{NO}_{\mathrm{x}}+P A N\right)$ and have a larger uncertainty in terms of absolute values than what is normally observed (Volz-Thomas et al., 2009 in preparation). Therefore, only the relative changes of $\left(\mathrm{NO}_{\mathrm{x}}+P A N\right)$ are discussed in the following.

\subsection{FLEXPART model simulations}

We use simulations with the FLEXPART Lagrangian particle dispersion model (version 6.2) (Stohl et al., 2005 and references therein) for long-range and mesoscale transport of tracers (anthropogenic and biomass burning emissions, and stratospheric ozone) in order to attribute sources to the MOZAIC observations. The simulations were done at NOAA as part of the ICARTT (International Consortium for Atmospheric Research on Transport and Transformation) analysis products (http://www.esrl.noaa.gov/csd/ ICARTT/analysis/) and at Laboratoire d'Aérologie. FLEXPART was driven by model-level data from the European Centre for Medium-Range Weather Forecasts (ECMWF). The ECMWF data has 60 model levels and was retrieved fully mass-consistently from the T511 spherical harmonics data at ECMWF. The gridded data has $1 \times 1$ degree resolution globally, but a $0.36 \times 0.36$ degree nest is used in the region $108^{\circ} \mathrm{W}-18^{\circ} \mathrm{E}$ and $18^{\circ} \mathrm{N}-72^{\circ} \mathrm{N}$. For anthropogenic emission input, the emission inventory of the EDGAR information system (version 3.2, Oliver and Berdowski (2001)) on a $1 \times 1$ degree grid is used outside North America. Over most of North America, the inventory of Frost et al. (2006) is used. This inventory has a resolution of $4 \mathrm{~km}$ and also includes a list of point sources. Previous experience has shown that Asian emissions of $\mathrm{CO}$ are underestimated (probably by as much as a factor of 2 or more) in the EDGAR inventory, while American $\mathrm{CO}$ emissions may be overestimated. For biomass fires, an emission inventory was constructed from daily MODIS fire hot spot detection and daily fire reports (see Annex A for a detailed description).

Backward simulations are done from along the flight tracks. Whenever an aircraft changes its position by more than 0.2 degrees in latitude or in longitude, a backward simulation is initiated. Also, whenever it changes by more than $400 \mathrm{~m}$ above $3 \mathrm{~km}$ altitude (with finer criteria at lower altitudes), a new backward simulation is initiated. Every simulation consists of 40000 particles released in the volume of air sampled. The backward simulations are done with full turbulence and convection parameterizations. The theory is described by Seibert and Frank (2004), and an application to aircraft measurements was presented by Stohl et al. (2003). The volume of air sampled is defined by four-dimensional boxes covering the latitudes, longitudes, altitudes, and times covered, depending on the geometry of the sampling. The products available from backward simulations are the socalled residence times, the source contributions and the emission tracer time series. A description is given in Annex A.

\subsection{Meso-NH model simulations}

The numerical simulation over the source region of biomass fire plumes was performed with the anelastic non-hydrostatic mesoscale model Meso-NH (Lafore et al., 1998). Lateral boundary conditions were adopted from large-scale operational analyses by ECMWF. The case was simulated with a horizontal grid spacing of $20 \mathrm{~km}$. The vertical grid had 75 levels up to $27 \mathrm{~km}$ with a level spacing of $40 \mathrm{~m}$ close to the surface to $500 \mathrm{~m}$ at high altitude. A sponge layer was installed from 22 to $27 \mathrm{~km}$ in order to damp the upward-propagating gravity waves generated by convection. The model grid had $120 \times 144$ horizontal gridpoints $\left(2400 \times 2880 \mathrm{~km}^{2}\right)$ and covered a domain centred over the Yukon, Canada (see Fig. 10 for the horizontal domain). The simulation was initialized at 12:00 UTC on 24 June 2004 for a duration of $60 \mathrm{~h}$. The subgrid-scale convection was parametrized by a mass-flux convection scheme (Bechtold et al., 2001). The time step of the model is $20 \mathrm{~s}$, and the convection scheme is called every 300 s (i.e., every 15 time steps). The microphysical scheme included the three water phases with five species of precipitating and non-precipitating liquid and solid water (Pinty and Jabouille, 1998), and a modified ice to snow autoconversion parameterization following Chaboureau and Pinty (2006). The turbulence parameterization was based on a 1.5-order closure (Cuxart et al., 2000). The turbulent flux computations were purely vertical using the mixing length of Bougeault and Lacarrére (1989) while, for the inner model, they were fully three-dimensional based on the parameterization of Deardoff (1974). The radiative scheme was the one used at ECMWF (Gregory et al., 2000) including the Rapid Radiative Transfer Model (RRTM) parameterization (Mlawer et al., 1997). Synthetic brightness temperatures (BTs) corresponding to the GOES (Geostationary Operational Environmental Satellites) observations were computed offline using the Radiative Transfer for Tiros Operational Vertical Sounder (RTTOV) code version 8.7 (Saunders et al., 2005).

\section{Observations of forest fire emission plumes}

The timetable of observations and model runs involved in the paper is shown in Table 1. Observations from two MOZAIC flights on 30 June 2004 are selected. During the first flight (referred to as MZ1 in the following) from Caracas (Venezuela) to Frankfurt (Germany), we analyse UTLS data during the cruise phase over the eastern Atlantic. During the second flight (referred to as MZ2 in the following) from Frankfurt (Germany) to Washington DC (USA), we analyse again UTLS data over the Eastern Atlantic and observations during the descent over Washington DC. Finally, we use the lidar measurements of aerosol backscatter cross-section taken at Wisconsin University (WI, USA) on 28 June. The 
Table 1. Time table of observations, model runs and age of simulations.

\begin{tabular}{|c|c|c|c|c|c|c|c|c|c|c|c|c|}
\hline \multirow[b]{2}{*}{ UTC } & \multicolumn{2}{|c|}{24 June 2004} & \multicolumn{4}{|c|}{25 June } & \multicolumn{3}{|c|}{26 June } & \multirow{2}{*}{$\begin{array}{c}28 \text { June } \\
15: 00\end{array}$} & \multicolumn{2}{|c|}{30 June } \\
\hline & $12: 00$ & 18:00 & 00:00 & 06:00 & $12: 00$ & $18: 00$ & 00:00 & 06:00 & $12: 00$ & & 03:00 & $18: 00$ \\
\hline Local Time & 05:00 h & $11: 00 \mathrm{~h}$ & $17: 00 \mathrm{~h}$ & $23: 00 \mathrm{~h}$ & 05:00 h & $11: 00 \mathrm{~h}$ & $17: 00 \mathrm{~h}$ & $23: 00 \mathrm{~h}$ & 05:00 h & $08: 00 \mathrm{~h}$ & $20: 00 \mathrm{~h}$ & $11: 00 \mathrm{~h}$ \\
\hline MOZAIC & & & & & & & & & & & MZ1 & MZ2 \\
\hline Lidar & & & & & & & & & & $X$ & & \\
\hline MODIS & & $X$ & & $\mathrm{X}$ & & & & & & & & \\
\hline FLEXPART MZ1 & $135 \mathrm{~h}$ & & & & $111 \mathrm{~h}$ & & & & & $36 \mathrm{~h}$ & start & \\
\hline FLEXPART MZ2 & $168 \mathrm{~h}$ & & & & $144 \mathrm{~h}$ & & & & & & & start \\
\hline Convection cycle & & Start & Max & End & & Start & Max & End & & & & \\
\hline Meso-NH & Start & & & & & & & & End & & & \\
\hline Age of BL tracer & & & $1 \mathrm{~h}$ & $7 \mathrm{~h}$ & $13 \mathrm{~h}$ & $19 \mathrm{~h}$ & $25 \mathrm{~h}$ & $31 \mathrm{~h}$ & $37 \mathrm{~h}$ & & & \\
\hline
\end{tabular}

links between these observations and emissions from boreal forest fires in North America will be established in Sect. 4.

The synoptic situation with respect to MZ1 observations (Fig. 1a) shows that the aircraft enters into the lowermost stratosphere by flying across the southernmost tip of an upper level trough. Near the axis of the upper-level trough at $20^{\circ} \mathrm{W}$, the aircraft is located in the lowermost stratosphere on the cyclonic-shear side of the upper-level jet (Fig. 1b). In accordance, MZ1 observations across the upper level trough (Fig. 2a) show characteristic changes of ozone and relative humidity, i.e. ozone is increasing from an uppertropospheric background of about $85 \mathrm{ppbv}$ (west of $26^{\circ} \mathrm{W}$ and east of $12^{\circ} \mathrm{W}$ ) to stratospheric mixing ratios in excess of $160 \mathrm{ppbv}$ inside the upper level trough (between $24^{\circ} \mathrm{W}$ and $13^{\circ} \mathrm{W}$ ), while relative humidity is decreasing from about $40 \%$ to $30 \%$. A closer examination of measurements at mesoscale (about $200 \mathrm{~km}$ ) in the lowermost stratosphere indicates a complicated structure with high variations of ozone and other trace gases. The enhanced values of $\mathrm{CO}$ and $\left(\mathrm{NO}_{\mathrm{x}}+P A N\right)$ and the well defined positive correlation between them clearly indicate that the southern tip of the upperlevel trough contains several tropospheric intrusions. The negative correlation of ozone with $\mathrm{CO}$ and with $\left(\mathrm{NO}_{\mathrm{x}}+P A N\right)$ suggests that the tropospheric intrusions had ozone mixing ratio lower than the stratospheric background value before their injection and that the mixing with the stratospheric air during the long-range transport has not reduced the ozone difference. The layout of the characteristic features of the trace gas time-series, i.e. a structure composed of 5 ozonerich maxima interlaced with $4 \mathrm{CO}$-rich and $\left(\mathrm{NO}_{\mathrm{x}}+P A N\right)$ rich maxima, suggests the axis of the upper-level trough at about $17^{\circ} \mathrm{W}$ is a meridional axis of symmetry, reducing the 4 tropospheric intrusions to 2 tropospheric filaments stretched out longitudinally and each sampled twice. Despite the lower accuracy of measurements taken with the MOZAIC relative humidity device in stratospheric air and its longer response time at low temperatures (about 1-2 minutes, i.e. horizontal resolution of about $15-30 \mathrm{~km}$ ), the positive correlation of relative humidity with $\mathrm{CO}$ and $\left(\mathrm{NO}_{\mathrm{x}}+P A N\right)$ inside the upper level trough confirms the tropospheric origin of the two fil- aments and their recent injection into the stratosphere. Also of interest is the positive correlation of ozone and deviations of the potential temperature $( \pm 1 \mathrm{~K})$ from its mean value of $335 \mathrm{~K}$, thus providing further evidence for the observation of tropospheric filaments in the upper level trough.

Within the tropospheric filaments embedded in the upper level trough, CO is about 200-250 ppbv, which suggests that the filaments are forest fire plumes, as it will be demonstrated in Sect. 4. The difference of ozone between the upper troposphere (about $85 \mathrm{ppbv}$ west of $26^{\circ} \mathrm{W}$ ) and the tropospheric-origin filaments in the lowermost stratosphere (minima ranging from $125 \mathrm{ppbv}$ to $150 \mathrm{ppbv}$ between $15^{\circ} \mathrm{W}$ and $22^{\circ} \mathrm{W}$ ) is about $40-65 \mathrm{ppbv}$, while the difference for $\mathrm{CO}$ is about $100-150 \mathrm{ppbv}$. Contributions to the difference in ozone likely come from both the photochemical production of ozone associated with forest fire emissions and from the mixing with stratospheric air. A contribution of a few tens of ppbv by the photochemical production of ozone is in agreement with Forster et al. (2001) who reported observations of tropospheric plumes of boreal forest fire emissions after continental-scale transport for which $\mathrm{O}_{3}$ mixing ratios were 25 ppbv higher than the tropospheric background. Using tropospheric $\mathrm{NO}_{2}$ columns derived from GOME satellite data, Spichtinger et al. (2001) demonstrated that $\mathrm{NO}_{2}$ concentrations in such boreal forest fire plumes can reach a magnitude comparable to the concentrations over major anthropogenic emission regions. As explained in Sect. 2, the MOZAIC $\mathrm{NO}_{\mathrm{y}}$ instrument was likely not detecting $\mathrm{HNO}_{3}$, which is corroborated by the abscence of normally observed correlation of $\mathrm{NO}_{\mathrm{y}}$ and $\mathrm{O}_{3}$ in the lower stratosphere on such mesoscale features. Although this would suggest that the $\mathrm{NO}_{\mathrm{y}}$ measurements should resemble the $\mathrm{NO}_{\mathrm{x}}$ or $\left(\mathrm{NO}_{\mathrm{x}}+P A N\right)$ concentration, there is a large uncertainty in the absolute value, which precludes the use of these measurements to further assess the ozone production. However, the relative changes are reliable and reinforce the conclusion of forest fire emissions injected into the lower stratosphere.

After refueling in Frankfurt, the same aircraft flew to Washington DC. MZ2 observations over the eastern Atlantic (Fig. 2b) show again similar signatures of tropospheric 


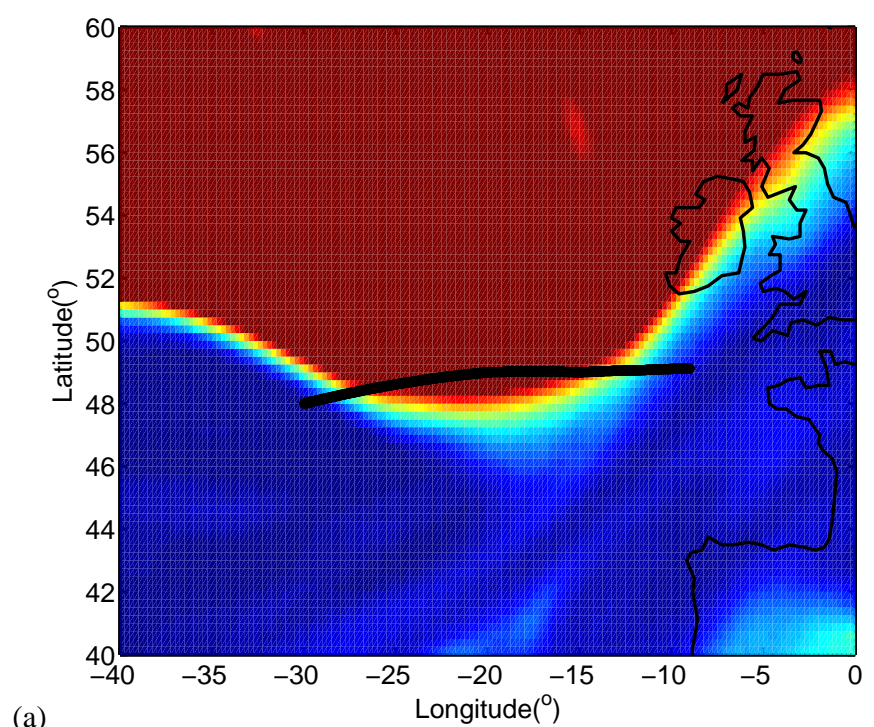

(a)

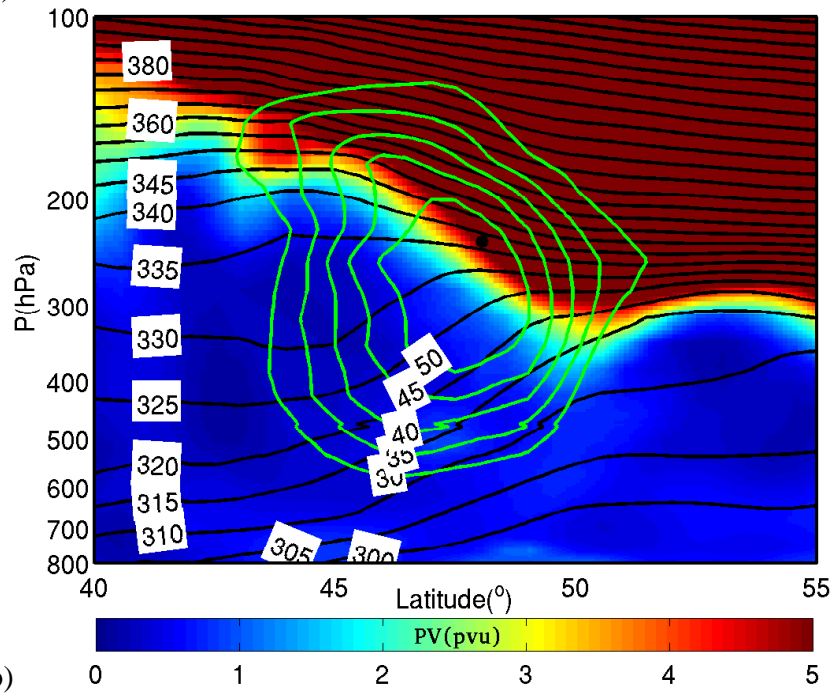

Fig. 1. Synoptic situation from ECMWF analyses on 30 June 2004, 03:00 UTC. (a) Potential vorticity $(p v u)$ at $250 \mathrm{hPa}$ with MOZAIC flight track in black. (b) Vertical and meridian cross-section along $20^{\circ} \mathrm{W}$ of potential vorticity ( $p v u$ ) with isentropic surfaces (black lines, K) and wind isotachs (green lines, $\mathrm{ms}^{-1}$ ). The black point in the lowermost stratosphere just above $335 \mathrm{~K}$ is the MOZAIC aircraft location.

intrusions into the lower stratosphere at around $0^{\circ} \mathrm{W}$ and at $1-2^{\circ} \mathrm{W}$ and in the isentropic layer $335-345 \mathrm{~K}$, just after the aircraft has crossed the tropopause east of $0^{\circ} \mathrm{W}$. Finally, over Washington DC (Fig. 3), several layers with biomass burning signatures (at about $4 \mathrm{~km}, 5 \mathrm{~km}, 7 \mathrm{~km}$ and $11 \mathrm{~km}$ altitude) have been encountered where ozone, carbon monoxide and nitrogen oxides are positively correlated. In all these layers $\mathrm{CO}$ is about $150 \mathrm{ppbv}, \mathrm{O}_{3}$ exceeds $60 \mathrm{ppbv}$ in layers at $4 \mathrm{~km}, 5 \mathrm{~km}$, and $7 \mathrm{~km}$ altitude, and $\mathrm{O}_{3}$ exceeds $170 \mathrm{ppbv}$ in the $11 \mathrm{~km}$ altitude layer (potential temperature $333 \mathrm{~K}$ ). It suggests different photochemistry regimes for the layers and

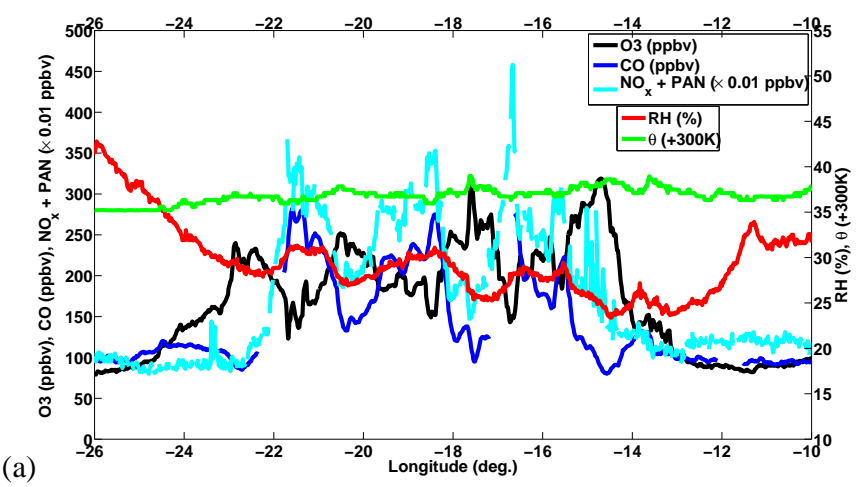

(a)

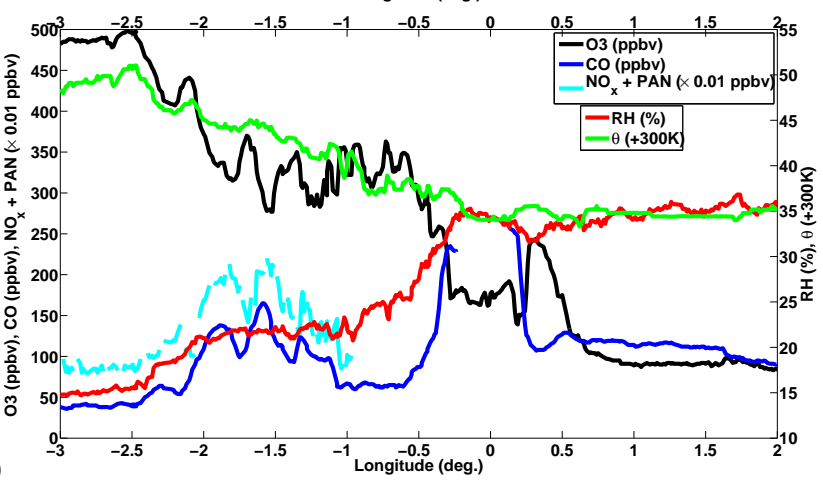

Fig. 2. MOZAIC observations. (a) Over the Atlantic on 30 June 2004 , from $26^{\circ} \mathrm{W}$ to $10^{\circ} \mathrm{W}$ at $10.5 \mathrm{~km}$ altitude. Referred hereafter as MZ1 observation. (b) Over the Atlantic on 30 June 2004, from $3^{\circ} \mathrm{W}$ to $2^{\circ} \mathrm{E}$ at $10.3 \mathrm{~km}$ altitude. Referred hereafter as MZ2 observations.

the possibility of mixing with stratospheric air for the highest layer. The repetition of such signatures on MOZAIC observations from 03:00 UTC (MZ1), to 10:00 UTC and 17:00 UTC (MZ2), and in different locations suggests one or more very active sources injecting biomass burning emissions into the stratosphere in large quantities.

Measurements obtained with the High Spectral Resolution Lidar (HSRL) (Eloranta, 2005) at the University of Wisconsin (location at $43.1^{\circ} \mathrm{N}, 89.4^{\circ} \mathrm{W}$ ) revealed strong signals of aerosol backscatter cross-section during the period 26 to 30 June that were attributed to fire smoke transported from Alaska and the Yukon Territory (Damoah et al., 2006). Of particular interest for our case study is the aerosol layer observed in the upper troposphere on 28 June (Fig. 4). The time-height contour of the aerosol backscatter cross-section shows 2 laminae with high optical thicknesses, a first lamina with a vertical extent of $500 \mathrm{~m}$ at $9 \mathrm{~km}$ altitude at 09:00 UTC that ascends to $12 \mathrm{~km}$ altitude at 18:00 UTC, and a second thicker lamina (vertical extent of $2 \mathrm{~km}$ ) at about $10.5 \mathrm{~km}$ altitude from 18:00 UTC to 24:00 UTC. Vertical profiles of backscatter ratio of cross-sections and temperature at 12:00 UTC show that the 2 laminae extend across the upper troposphere and above the tropopause situated below $10 \mathrm{~km}$ altitude. 


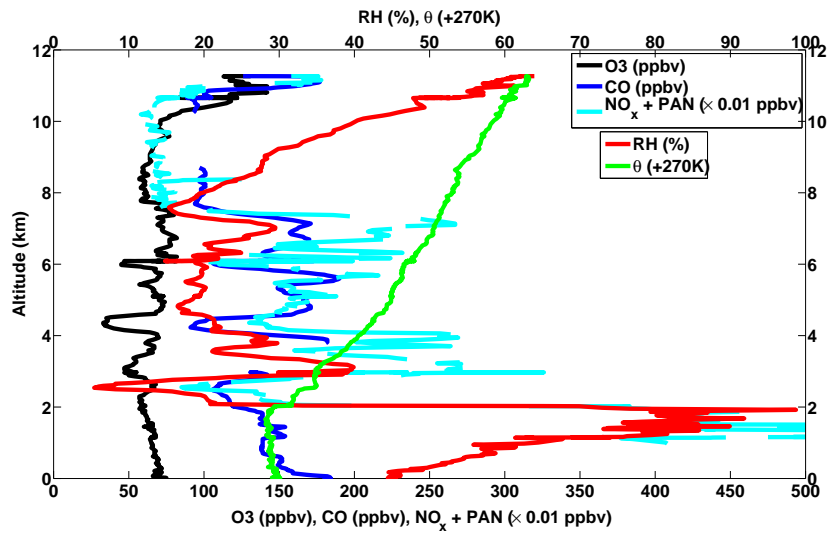

Fig. 3. MOZAIC observations in the vertical sounding in Washington DC, 30 June 2004, 17:00 UTC. Referred hereafter as MZ2 observations. The absence of data corresponds to internal calibrations periods.

\section{Identification of the source region of forest fire emis- sions}

Plots for emission tracer time series constructed from the FLEXPART backward simulations along the MZ1 flight are displayed in Fig. 5. During the period of interest (between 02:50 UTC and 0414 UTC on 30 June, or equivalently between 26.8 and $28.2 \mathrm{~h}$ past 00:00 UTC on 29 June 2004), FLEXPART calculations indicate that MOZAIC measurements are marginally impacted by Asian anthropogenic pollution (only 2-3 ppbv for CO, not shown) and not at all impacted by North-American (Fig. 5c) and European anthropogenic pollution (not shown). Impact of surface emissions during that period exclusively come from the biomass burning $\mathrm{CO}$ over North America, with a contribution up to $110 \mathrm{ppbv}$ when using a $10 \mathrm{~km}$ injection altitude into the atmosphere of the smoke. Adding a typical CO background of about $100 \mathrm{ppbv}$ for the upper troposphere, the sum exceeds 210 ppbv which is close to the MZ1 observations (Fig. 2a). The sensitivity analysis to the assumed injection height (Figs. $5 a-b)$ shows that the air mass of interest, which is 5-6 days old, is impacted substantially only if an injection height of up to $10 \mathrm{~km}$ altitude is used. An injection height of up to $3 \mathrm{~km}$ is insufficient to explain the observations. While FLEXPART was run with the convection scheme turned on, it pumped up only a few ppbv of $\mathrm{CO}$ when the fire emissions were injected near the surface. Thus, the convection was insufficiently captured by the model, probably because it was also invigorated by the fire itself, a process not at all included in FLEXPART. However, in Sect. 5 we shall see that a higher-resolution simulation with Meso-NH was able to capture the convective injection of the smoke to high altitudes.

The emission tracer time series for the UTLS part of the MZ2 flight (between 10:00 UTC and 11:00 UTC) confirms the predominant contribution of fire emissions (Fig. 6a) to the MZ2 tropospheric intrusions compared to other sources (see Fig. 6c for the North-American anthropogenic pollution). The fire $\mathrm{CO}$ emissions contribute up to $90 \mathrm{ppbv}$ to the $\mathrm{CO}$ plumes. Again, the vertical transport by deep convection is clearly suggested by the sensitivity study on injection heights (Figs. 6a-b). Around 17:00 UTC during the descent over Washington DC, the emission tracer time series indicates a combination of impacts of anthropogenic pollution from Asia (not shown) and North America (Fig. 6c) as well as biomass burning CO from North America (Fig. 6a). At $11 \mathrm{~km}$ altitude, the CO contribution of Asian emissions is a few ppbv (not shown), while again the fire $\mathrm{CO}$ emissions over North America (Fig. 6a) contribute to volume mixing ratio as high as $100 \mathrm{ppbv}$ if injection heights are up to $10 \mathrm{~km}$ altitude. In the middle and lower troposphere, American anthropogenic pollution adds a $\mathrm{CO}$ contribution ranging from 40 to $80 \mathrm{ppbv}$, while the contribution from fire $\mathrm{CO}$ emissions over North America decreases to a maximum of 20 ppbv.

Plots for emission tracer time series constructed from the FLEXPART backward simulations along the MOZAIC observations have allowed us to identify the nature of emissions and the mechanism of vertical transport responsible for the tropospheric intrusions presented here, i.e. biomass fire $\mathrm{CO}$ emissions and deep convection, respectively. Now, we analyse biomass fire $\mathrm{CO}$ source contributions along MOZAIC flight tracks to locate the sources in space and time. Whatever sections of MOZAIC observations shown on Figs. 2 and 3 are chosen, the source contribution comes invariably from North West America (Alaska, Yukon and North-West Territories); hence maps of biomass fire CO source contributions (Fig. 7) are shown only for the MZ1 observations and the MZ2 observations in the free troposphere during the descent to Washington DC. The calculation of these source contributions assumed an injection height of below $3 \mathrm{~km}$, so the observed $\mathrm{CO}$ concentrations are underestimated. However, the maps do point out the source region producing the smoke and also confirm that FLEXPARTs convection scheme pumped up smoke to high altitudes in this region, albeit in too low quantities. Maps for the footprint residence times constructed from MOZAIC observations keep essentially the same patterns on the period from 24 June 12:00 UTC to 25 June 12:00 UTC (not shown). This 24-h period starts at the minimum phase of the local diurnal cycle of the convection over Yukon and Alaska (where local time is UTC minus $7 \mathrm{~h}$ ), and spans a complete diurnal cycle (see Table 1 for the timetable of the case study). In line with the previous results, the starting date of the Meso-NH simulation (Sect. 5) is chosen on 24 June 12:00 UTC.

For the connection between lidar observation at Wisconsin University (Fig. 4) and MOZAIC observations in the eastern Atlantic upper level trough (Fig. 2a), we analyse backwards calculations of FLEXPART initialized along the MOZAIC observations. It is shown in Fig. 8 the residence time distribution in the whole atmospheric column for trajectory particles 
(a)

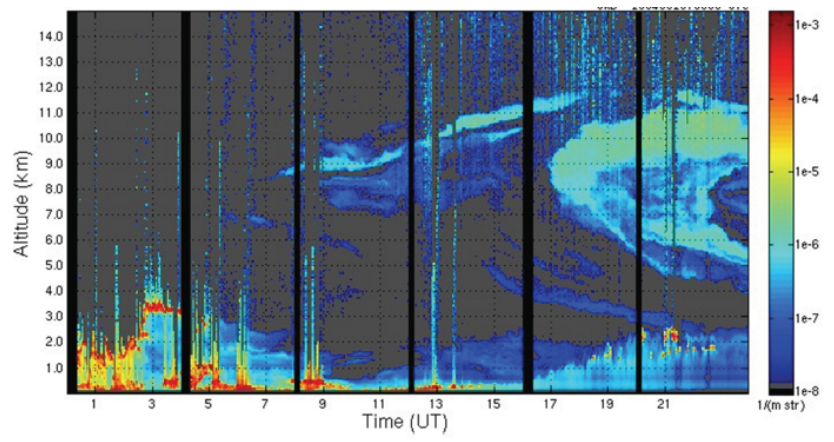

(b)

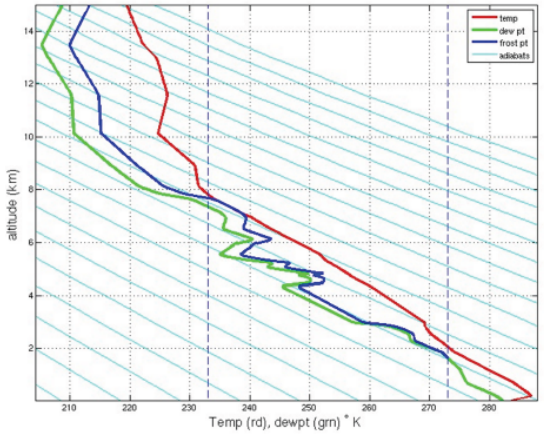

(c)

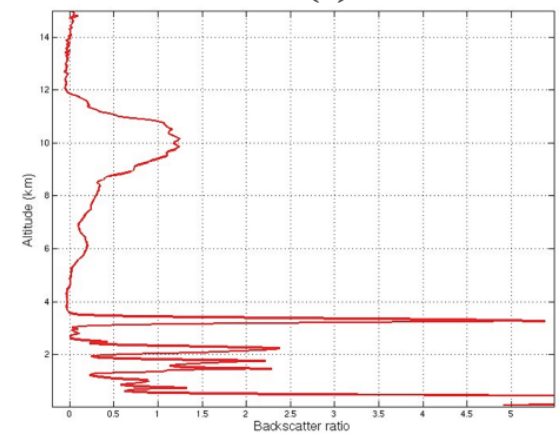

Fig. 4. Observations on June 28th 2004 from the Madison lidar (Wisconsin University, WI, USA) (a) Time series of vertical profiles of aerosol backscatter cross-section. (b) Vertical profile of temperature (red, K) and dew point (green, K). (c) Backscatter ratio at 1200 UTC from lidar data.

initialized in small receptor boxes ( 0.5 latitude and longitude, $500 \mathrm{~m}$ thickness) along the MZ1 MOZAIC aircraft route on 30 June 03:00 UTC within a 1-h time interval. Particles were released only from boxes where the measured $\mathrm{CO}$ exceeded 200 ppbv. Residence times were calculated from initialisation until $36 \mathrm{~h}$ back (valid on 28 June 15:00 UTC) which corresponds to the observing time period by the lidar. The westernmost part of the residence time distribution (i.e. the retroplume) lies over Wisconsin, approximately at the time and the location for which lidar observations of the aerosol layer were performed (see Fig. 4). Thus, the transport model establishes a quasi-Lagrangian connection between the MZ1 MOZAIC observations and the lidar observations and confirms that smoke aerosols are associated with high CO mixing ratios.

Forward calculations of the FLEXPART model for the distributions of a stratospheric ozone tracer and of a biomass burning CO tracer (Stohl et al., 2000; Cooper et al., 2005) were also analysed to further strengthen the value of the case study. The analyses are not reported here for the sake of brevity and because simulations assumed $3 \mathrm{~km}$ injection height (not $10 \mathrm{~km}$ altitude). Interpretations confirm that i) the aircraft observations are performed in the lower stratosphere on the cyclonic-shear side of the upper-level jet, ii) the tropospheric intrusions are organized in filaments stretched along the upper-level jet. Forward calculations also suggest mixing between the stratospheric background and the fire plumes to have taken place.

All FLEXPART results contribute to assign the northwestern America region as the source region of plumes of forest fire emissions observed with MOZAIC aircraft and the Madison lidar. This statement can be further reinforced by the examination of satellite data products over the region of interest. The MODIS satellite image over Yukon on June 24th 1955 UTC (12h55 local time) (Fig. 9a) shows smoke of biomass fires in a large region west of Great Bear Lake with satellite-detected biomass fire spots (red points) and deep convective cells just forming southwest of the lake at about $64^{\circ} \mathrm{N}-130^{\circ} \mathrm{W}$. At 22:35 local time on the same day, another MODIS satellite image (Fig. 9b) shows smoke of biomass fires, and deep convective cell tops during the mature phase of the diurnal cycle of convection. On 25 June 18:40 UTC (11:40 local time), the NASA TOMS aerosol index displays high values in the region (not shown), indicative of increasing aerosol optical depth, due to a vertical piling up of aerosols caused by the deep convection, and because the instrument is more sensitive to absorbing aerosols at greater altitudes (Fromm and Servranckx, 2003; Fromm et al., 2005).

To summarize about the continental-scale transport of plumes of forest fire emissions, the transport model has established quasi-Lagrangian connections between MOZAIC (MZ1) observations on 30 June and lidar aerosol data at 


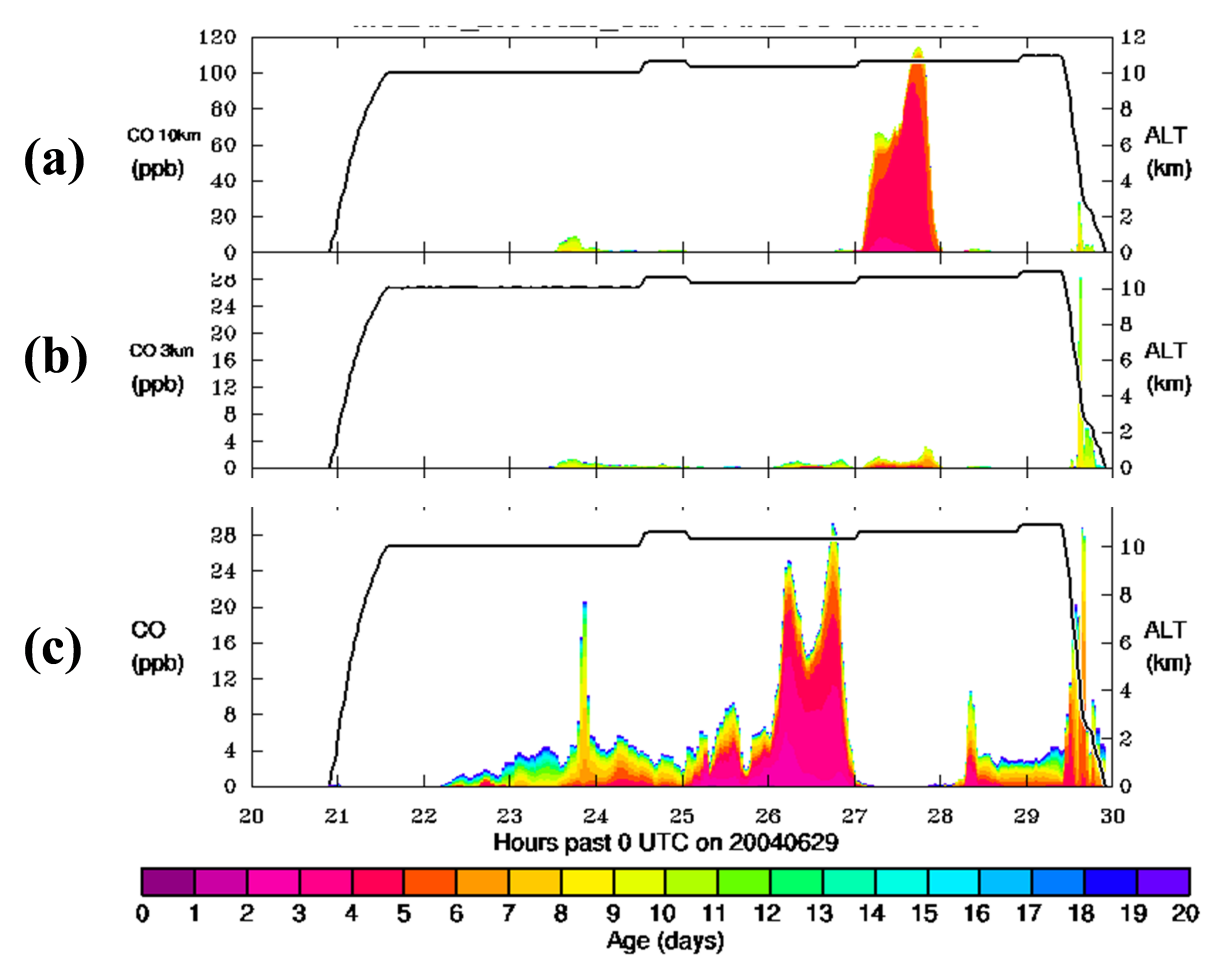

Fig. 5. Emission tracer constructed from the FLEXPART backward simulations along the entire MZ1 MOZAIC flight as time series. Hours are counted past 00:00 UTC on 29 June 2004. The MZ1 observations are shown on Fig. 2a and occur between 26.8 and 28.2 h past 00:00 UTC on 29 June 2004. The colored contours indicate the age (days) of air masses considered. Values on the y-coordinate indicate either the aircraft altitude (black line, $\mathrm{km}$ ) or the CO mixing ratio (ppbv) of air masses considered. Biomass burning CO (ppbv) for different assumptions on the injection altitude: (a) below $10000 \mathrm{~m}$ and (b) below $3000 \mathrm{~m}$. Results for injection altitude below $1000 \mathrm{~m}$ and below $150 \mathrm{~m}$ are similar to those for injection altitude below $3000 \mathrm{~m}$ (not shown). (c) Total anthropogenic North American pollution from CO (ppbv).

Madison (University of Wisconsin, USA) on 28 June, as well as between MOZAIC observations (MZ1 and MZ2) on 30 June and satellite observations (TOMS aerosol index and MODIS images) of boreal forest fires over Northwestern America on 24 and 25 June. The focus of the next section is to assess the ability of a mesoscale model to reproduce the UTLS injection of biomass fire emissions over this boreal region.

\section{Meso-scale modeling over the source region and UTLS injection}

Table 1 summarizes the timetable of the Meso-NH run involved in the paper. As described in Sect. 3, the largest FLEXPART sensitivities for MZ1 and MZ2 observations to emission input over American boreal regions span over the period from 24 June 12:00 UTC to 25 June 12:00 UTC (i.e. 5 to 6 days prior to MOZAIC observations). Therefore, this first date is chosen as initialization date of the mesoscale model Meso-NH over the boreal domain in order to simulate the diurnal convection cycle during a 48-h period of time.
First, an evaluation of the Meso-NH simulation with regard to convection triggering and upper-level cloud cover is made by comparing synthetic and GOES observed radiances. A model-to-satellite approach (Chaboureau et al., 2000, 2002) combines the explicit Meso-NH cloud scheme with a detailed radiative-transfer code. A comparison at the end of the convective diurnal cycle on 25 June 06:00 UTC ( $23 \mathrm{~h}$ local time) is made between the GOES observed radiances and the Meso-NH outputs (Fig. 10). Overall, the comparison is good, although there are slightly more extensive upper-level clouds by the model. Such an overestimation may result from at least 3 reasons: an earlier triggering of the modeled convection compared to observations, an overestimated water residence time in the upper atmosphere, or a too large water detrainment. To further evaluate the simulation with regards to the cloud top heights, Fig. 11 shows the time evolution of the brightness temperature minimum values over the model domain, both in the GOES observations and the simulation. Minimum values are around $215 \mathrm{~K}$, which suggests that deep convective clouds have reached the tropopause. Indeed, as it can be checked with radiosounding data available in the model 


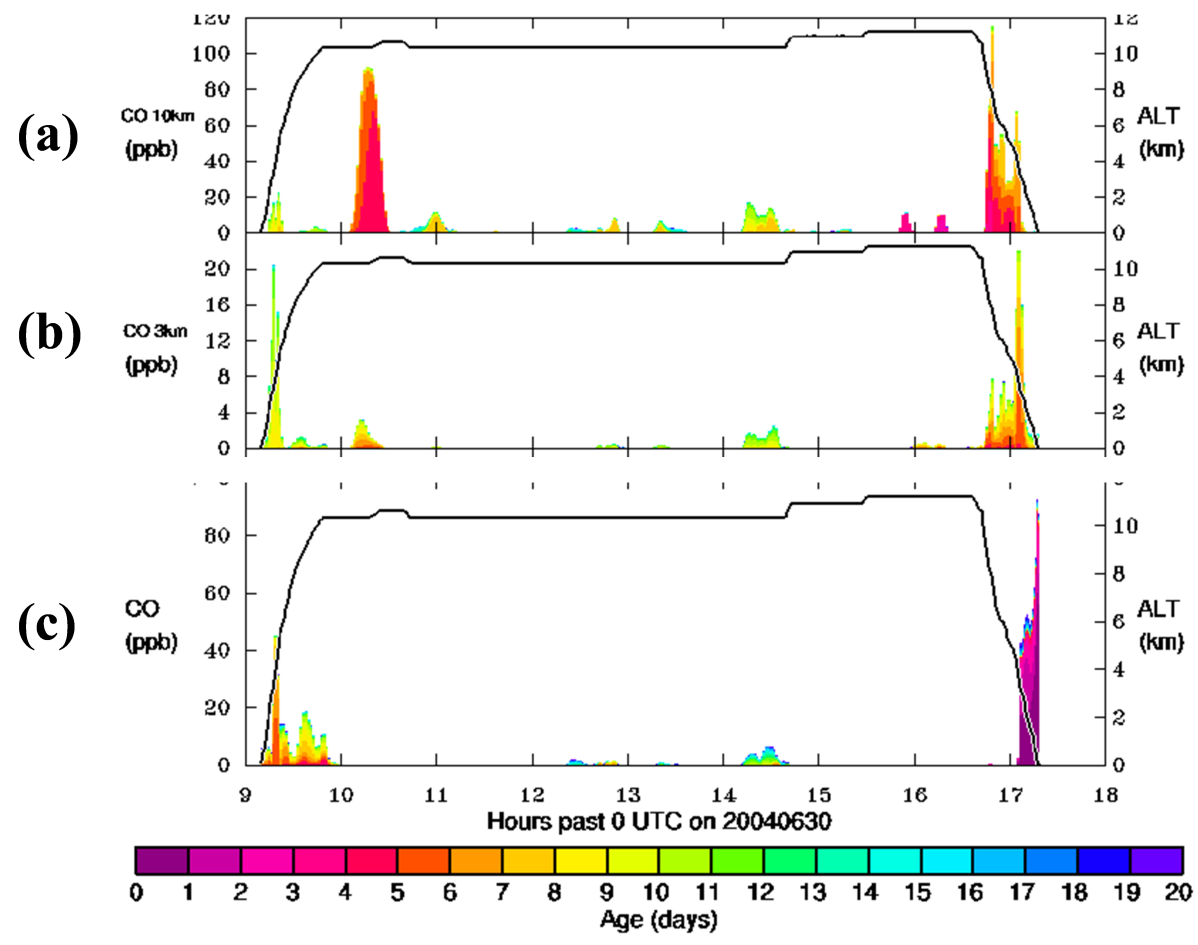

Fig. 6. As for Fig. 5 but for the MZ2 MOZAIC flight. Hours are counted past 00:00 UTC on 30 June 2004. The MZ2 observations are shown on Fig. 2 b and occur between 9.8 and 10.6 hast 00:00 UTC on 30 June 2004.

domain (Department of Atmospheric Sciences, University of Wyoming, http://weather.uwyo.edu/upperair/sounding.html) the tropopause (cold point temperature) over the area (Fort Nelson at $58.8 \mathrm{~N}-122.6 \mathrm{~W}$, Whitehorse at $60.7 \mathrm{~N}-135.1 \mathrm{~W}$, and Norman Wells at $65.3 \mathrm{~N}-126.7 \mathrm{~W}$ ) from 24 to 26 June was at about $12 \mathrm{~km}$ with an average temperature of $215 \mathrm{~K} \pm 3 \mathrm{~K}$. This is also the case in the Meso-NH simulation for which the temperature minimum at the tropopause is close from $215 \mathrm{~K}$ and is near the 2 pvu isoline (see Fig. 13a). Such a qualitatively good comparison represents the state of the art with regards to mesoscale modeling and it would be beyond the scope of this study to further assess the cloud representation by the model.

Then, in order to describe the mass transport associated with the convective clouds, a boundary layer tracer (BL tracer for short) is initialized on 24 June 23:00 UTC (16:00 h local time), i.e. at a time close to the maximum diurnal development of the boundary layer. Hence, the BL tracer is one hour old on 25 June 00:00 UTC and $37 \mathrm{~h}$ old at the end of the Meso-NH simulation on 26 June 12:00 UTC (see Table 1). The BL tracer is initialized to 1 between the ground and the top of the boundary layer and to 0 above the top of the boundary layer. According to Cuxart et al. (2000), the top of the boundary layer is defined with a threshold of turbulent kinetic energy $\left(0.01 \mathrm{~m}^{2} \mathrm{~s}^{-2}\right)$. The BL tracer is transported at each time step of the model by the explicit (grid-resolved) 3D circulation and by sub-grid (parameterized) transport asso- ciated with turbulence, convection and diffusion. The overall objective is to investigate how much of the BL tracer is detrained at the convective cloud top levels and how well it mimics the uplifting of fire smoke at the isentropic levels for which downwind MOZAIC observations were performed.

The mass transport associated with convective clouds is then investigated with Meso-NH outputs on 25 June 00:00 UTC (17:00 h local time); i.e. one hour after its initialisation and close to the maximum activity of the first simulated convective diurnal cycle (see Table 1). Figure 12a shows the height of convective clouds reaching up to $13 \mathrm{~km}$ altitude and the large scale upper-level jet meandering clockwise around the center of the domain (referred to as the anticyclonic flow for short hereafter). We developed an indicator of the characteristic time needed by convective mass fluxes to fill up a 3-D grid box of the model (i.e. a box of $20 \mathrm{~km}$ horizontal length and $500 \mathrm{~m}$ height) with air pumped out by updrafts (positive values) or downdrafts (negative values). This indicator is called the convective indicator hereafter. When the convective indicator is equal to $1(0.5)$, its associated characteristic time to fill up a grid volume is 5 (10) h. In Fig. 12b, the distribution of the indicator is shown on the 2-pvu tropopause surface which lies inside the cloud detrainment layer (CDL for short, a vertical perspective of the CDL is shown in Fig. 13a). Fig. 12b shows that for the most intense convective cells, updrafts replace the air contained in a model grid box at the tropopause with air pumped 


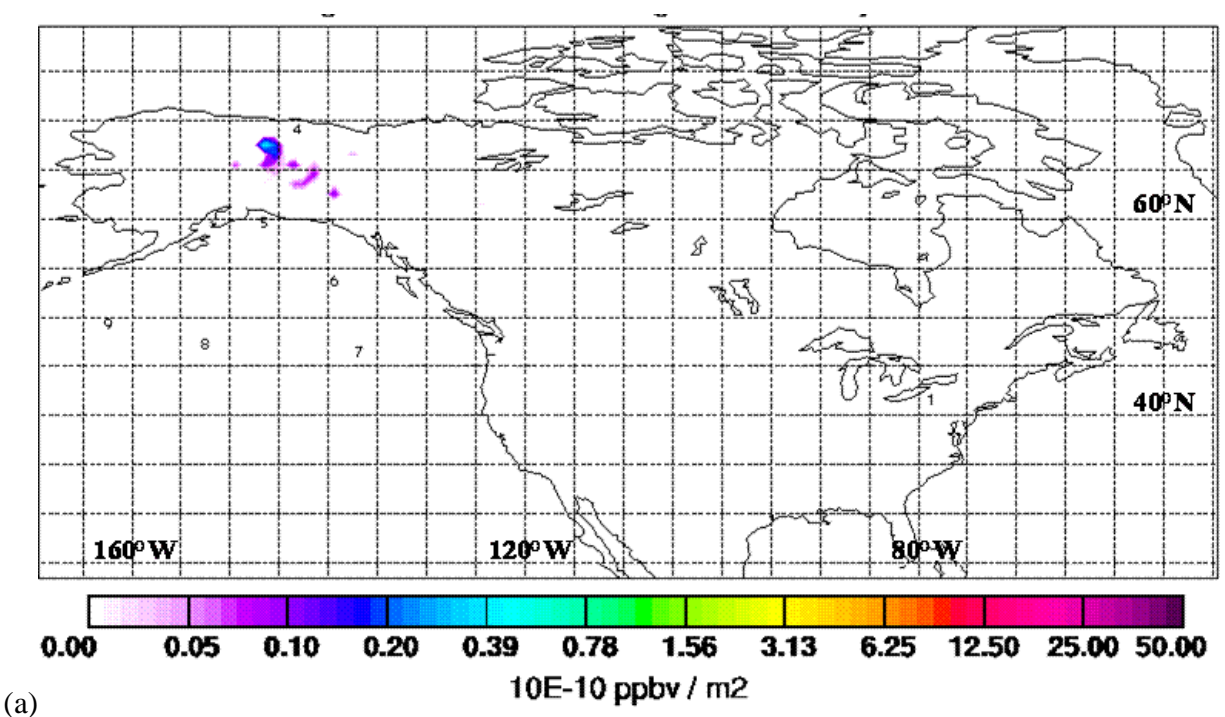

(a)

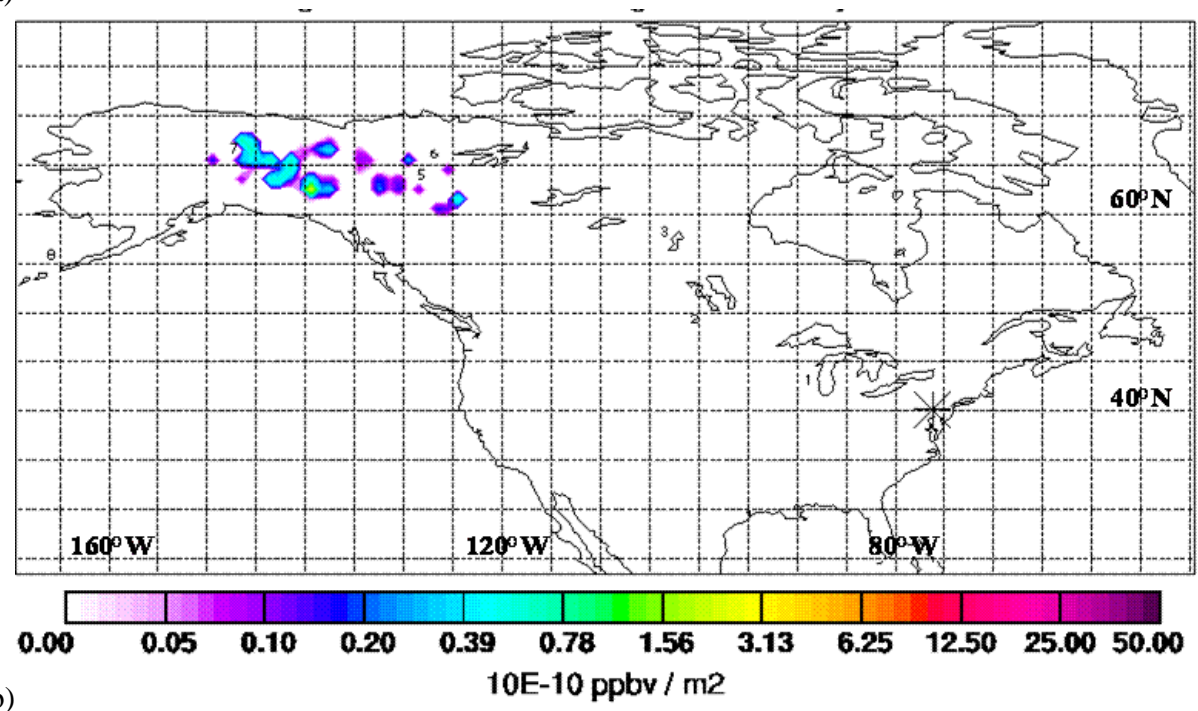

Fig. 7. Biomass fire $\mathrm{CO}$ source contributions (ppbv per square meter) from the FLEXPART backward simulations along MOZAIC observations. (a) For the MZ1 observations around 03:36 UTC on 30 June 2004, at $10.5 \mathrm{~km}$ altitude and $19^{\circ} \mathrm{W}$ (see Fig. 2a). (b) For the MZ2 observations around 16:56 UTC on June 30th, 2004, at $5.5 \mathrm{~km}$ altitude over Washington DC (see Fig. 3).The asterisk shows the position of the aircraft.

out at the root of the updrafts in a characteristic time of 5 to $7.5 \mathrm{~h}$, which is the order of magnitude of the lifetime of convective cells. Figure $12 \mathrm{~b}$ also indicates that convective mass fluxes cross the $330 \mathrm{~K}$ and $335 \mathrm{~K}$ isentropic surfaces where MOZAIC observations are performed. Note that over the area of interest, the 2-pvu tropopause surface is mostly slightly below the $335 \mathrm{~K}$ isentropic surface in the model outputs, except nearby some of the deep convective cells where it is slightly above this surface (see also vertical cross sections in Figs. 13 and 15). The outflow above deep convective cells over the area of interest is embedded in the anticyclonic flow, which is in agreement with FLEXPART retro-plume calculations (Fig. 7).
The vertical perspective of convective mass fluxes is given in Fig. 13a which shows a vertical cross-section going across the main deep convective cells west of Great Bear Lake (see location on Fig. 12a). Updrafts lead to positive characteristic times (about $7.5 \mathrm{~h}$ ) of the convective indicator in the CDL across the 2-5 pvu lowermost stratosphere region. Downdrafts lead to negative characteristic times (about $5 \mathrm{~h}$ ) of the convective indicator within the boundary layer. Figure $13 \mathrm{~b}$ shows the concentration of the boundary layer tracer. It is close to 1 in the boundary layer. Due to convective mass fluxes, the BL tracer is transported up to the tropopause region through the short-circuit of updrafts with flow rates leading to maximum concentrations at $335 \mathrm{~K}$ of about 15 to 


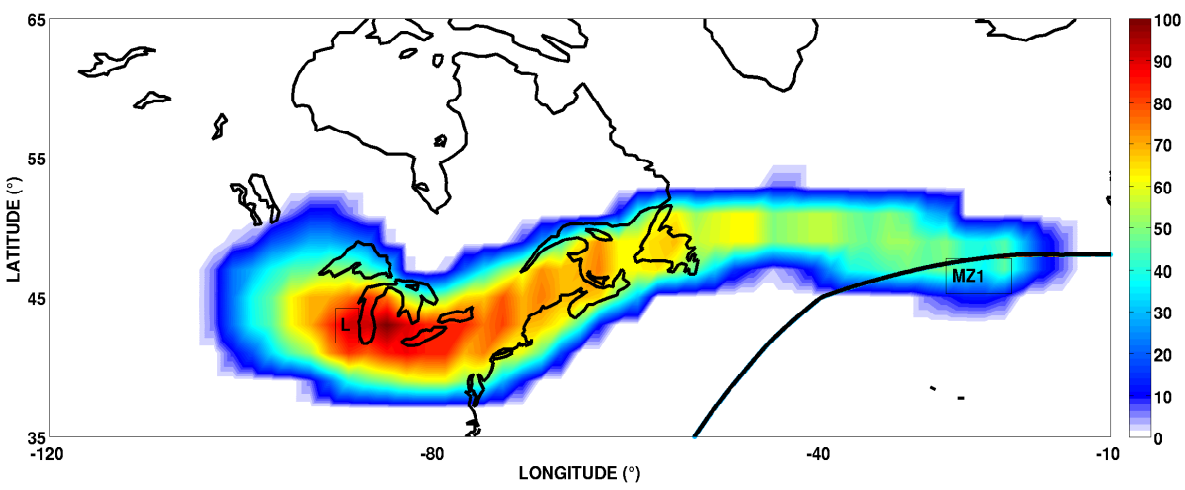

Fig. 8. Residence time distribution in the whole atmospheric column for trajectory particles arriving in small receptor boxes $(0.5$ latitude and longitude, $500 \mathrm{~m}$ thickness) along the MZ1 MOZAIC aircraft route on 30 June 2004 within a 1-h time interval. Particles were released only from boxes where the measured CO exceeded 200 ppbv. Residence times were calculated from arrival until $36 \mathrm{~h}$ back ( 28 June 2004 , 15:00 UTC) and values are given as percentages of the maximum $(20 \mathrm{~h})$. The MOZAIC aircraft trajectory between Caracas and Frankfurt is superposed (black line), the label MZ1 stands where the 275-ppbv maximum CO mixing ratio is located. The label L stands where the lidar observation at Wisconsin - Madison University are performed (Fig. 4).

$20 \%$ of the initial concentration in the boundary layer. Because of the initialization time of the boundary layer tracer on 24 June 23:00 UTC (16:00 h local time), the BL tracer is just one hour old in the vertical cross-section. Its transport has mainly been carried out by deep convective cells, with a negligible transport by explicit vertical advection (whose maximum intensity, as indicated by black arrows, is about $0.2 \mathrm{~ms}^{-1}$ ) and by weak horizontal winds on the border of the anticyclonic flow. The time period of horizontal transport of the BL tracer is insufficient for it to appear at upper levels in the southward branch of the anticylonic flow on the eastern part of the cross-section.

Two snapshots of the BL tracer distribution on the $335 \mathrm{~K}$ isentropic surface are shown in Fig. 14. The time evolution shows how the BL tracer wraps up along the anticyclonic flow around the Great Bear Lake and turns into the southward branch in agreement with retro-plume calculations of FLEXPART. Note that (i) lateral boundary conditions prevent the BL tracer exiting on the eastern edge of the model domain from being seen, (ii) there is an underestimation of the BL tracer concentration with time and away from the source region as the transport scheme of Meso-NH is known to be somewhat too dissipative. Note also that the BL tracer emitted at the centre of the domain may also exit the model domain directly when embedded in the southeastward branch of the anticyclonic flow. Nonetheless, FLEXPART calculations did not link up MZ1 and MZ2 observations to this particular pathway.

A vertical perspective of the BL tracer is shown at a later time in a vertical section (Fig. 15) across the northward and southward branches of the anticyclonic flow (see location on Fig. 14b). It shows that the BL tracer concentration reaches $15 \%$ to $20 \%$ at some places in the tropopause region. According to Meso-NH results, the maximum concentration of the $\mathrm{BL}$ tracer at $335 \mathrm{~K}$ in the lowermost stratosphere over the Yukon source region is about 15-20\%. Comparing with downwind MZ1 observations of $\mathrm{CO}$ mixing ratio of about $275 \mathrm{ppbv}$, and ignoring the mixing processes during the longrange transport, it would signify that the $\mathrm{CO}$ mixing ratio in the boundary layer over Yukon is in excess of 1.41.8 ppmv. That seems very reasonable according to $\mathrm{CO}$ observations of a few $10 \mathrm{ppmv}$ in Canadian boreal forest fires (e.g. Cofer et al., 1998 ; Goode et al., 2000). Available from the National Air Pollution Surveillance network of Canada (http://www.etc-cte.ec.gc.ca/NAPS/), CO surface measurements at Yellowknife (capital of the Northwest Territories on the north shore of Great Slave Lake) indicate (not shown) summer monthly means of $0.6 \mathrm{ppm}, 0.8 \mathrm{ppm}$ and $0.9 \mathrm{ppm}$ in June, July, and August 2004, respectively compared to less than $0.1 \mathrm{ppm}$ for all summer months in 2005 .

\section{Conclusions}

Boreal forest fires cause strong disturbances of atmospheric chemistry in the northern hemisphere. In this paper, we report on in-situ observations during MOZAIC flights of biomass fire plumes injected into the lower stratosphere. The fact that multiple $\mathrm{CO}$ plumes were observed on 30 June 2004 at several places over the eastern coast of the United States and over the eastern Atlantic indicates that duration and flowrate of the injection into the lowermost stratosphere are linked to an active vertical transport mechanism. Simulations of the pathways of airmasses with the particle dispersion model FLEXPART have identified the sources of these plumes, i.e. the large forest fires in Canada and Alaska. A sensitivity analysis to the injection height used in FLEXPART indicates that vertical transport by deep convection up 


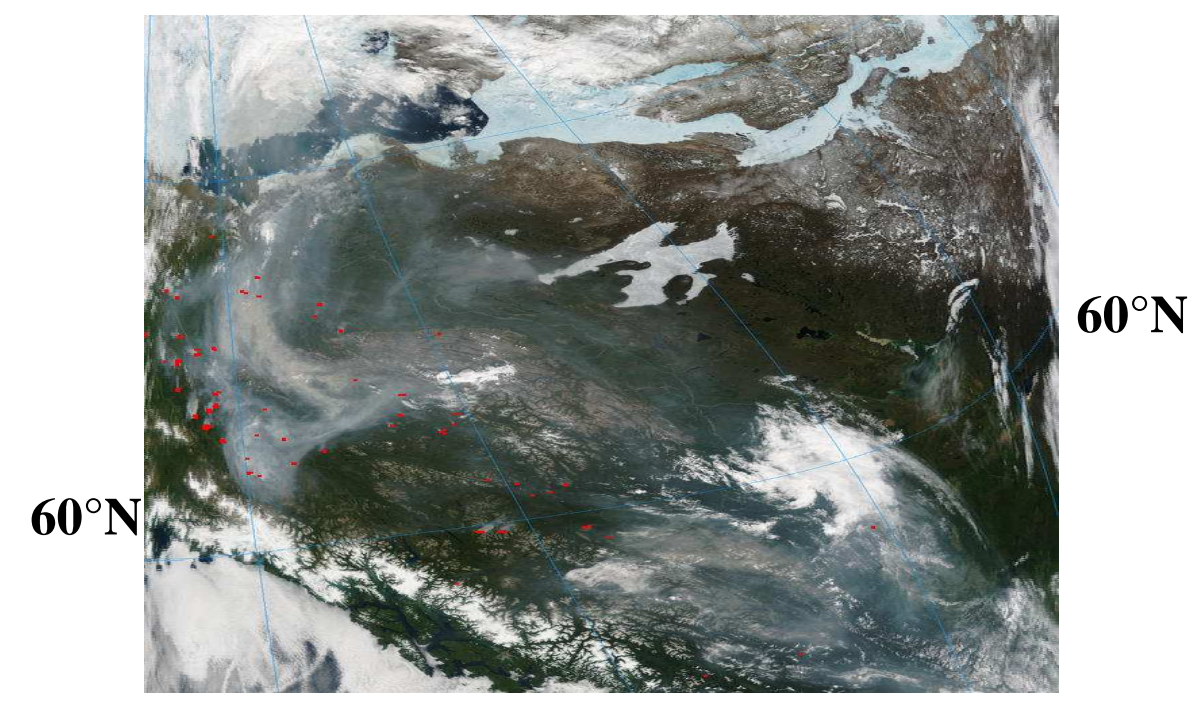

(a)
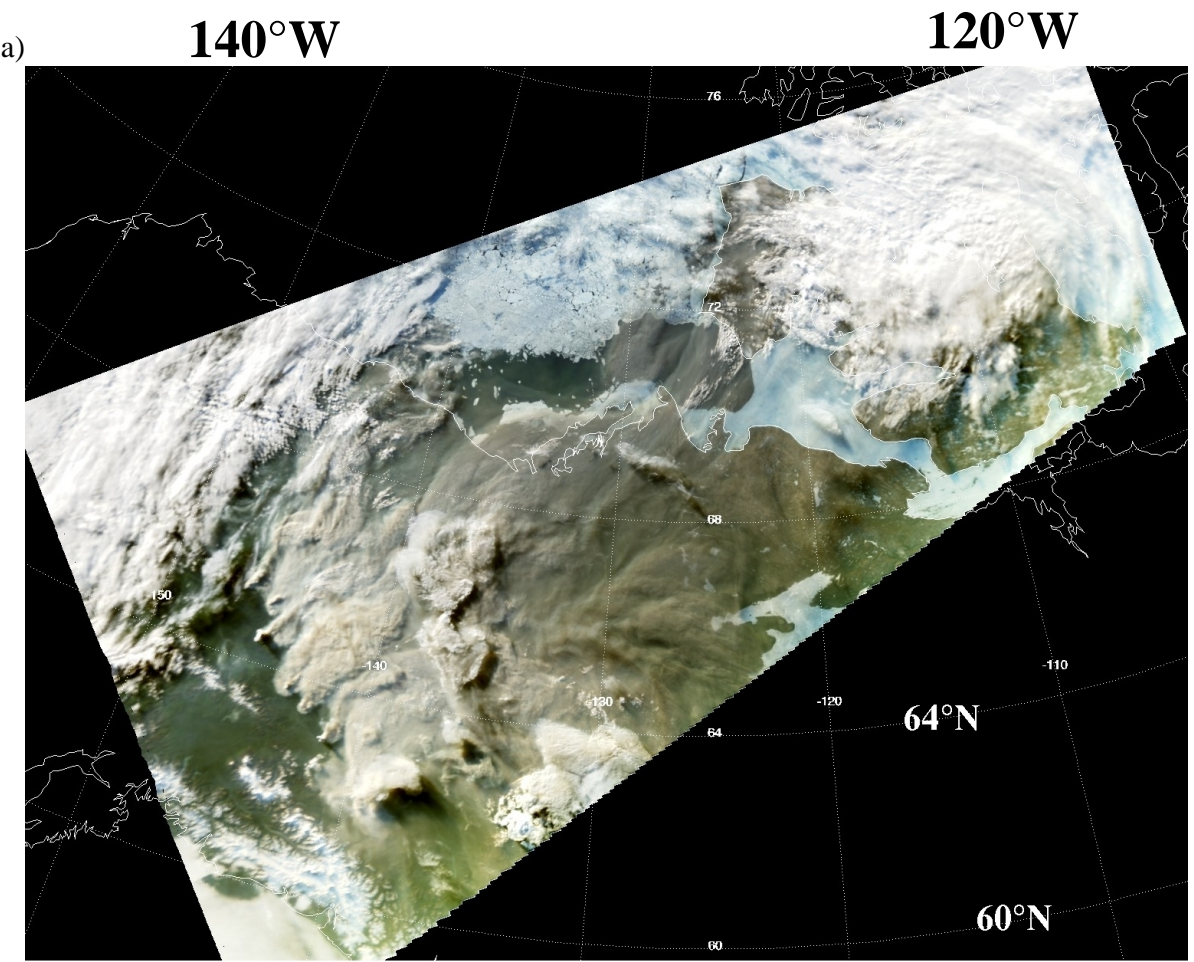

(b)

$140^{\circ} \mathrm{W}$

$120^{\circ} \mathrm{W}$

Fig. 9. MODIS images. (a) On 24 June 2004, 19:55 UTC (12:55 h local time) showing the smoke and incipient convection over the Great Bear Lake region in northwest Canada. (b) On 25 June 2004, 05:35 UTC (22:35 h local time the day before) over Yukon showing mature convective cells with biomass fire smoke west of the Great Bear Lake

to $10 \mathrm{~km}$ altitude is necessary to explain the observations. A simulation of the non-hydrostatic Meso-NH model over the domain of boreal forest fires was capable of reproducing the mechanism of injection into the lower stratosphere. A boundary layer tracer, vertically transported with the subgrid-scale convection parametrized by a mass-flux convection scheme, reaches above the dynamical tropopause into the isentropic layer $(>335 \mathrm{~K})$ in which the plumes were observed downwind. The parameterized convective detrainment flux is intense enough to fill the volume of a model mesh $(20 \mathrm{~km}$ horizontal, $500 \mathrm{~m}$ vertical) above the tropopause with pure boundary layer air in a time period compatible with the convective diurnal cycle, i.e. about $7.5 \mathrm{~h}$. Maximum instantaneous detrainment fluxes deposited about $15-20 \%$ of the 


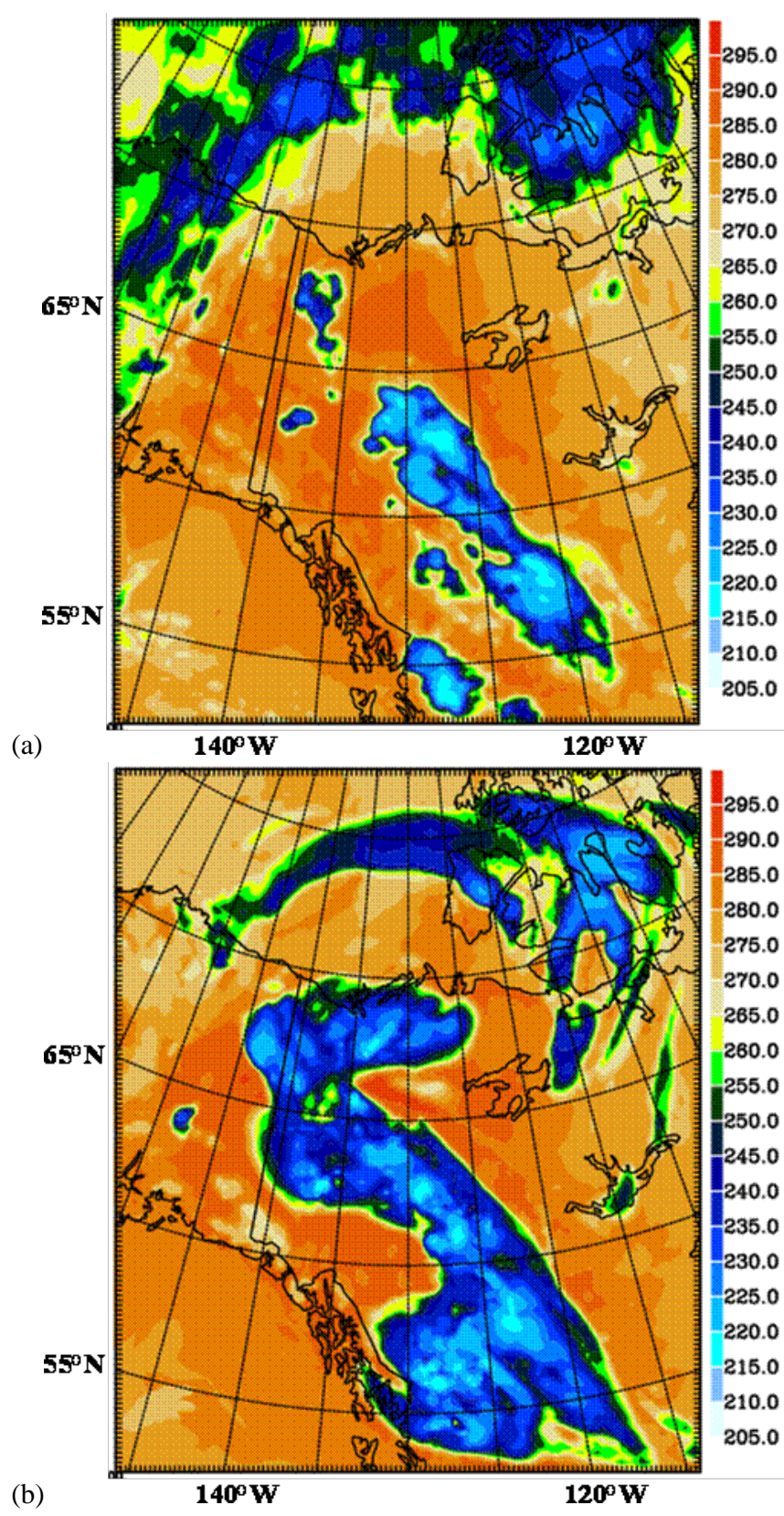

Fig. 10. Validation of Meso-NH run by comparison between (a) GOES 10, 10.7 micron brightness Temperature, 25 June 06:00 UTC (23:00 h local time the day before) and (b) Meso-NH 10.7 micron brightness Temperature 25 June 06:00 UTC (23:00 h local time the day before).

initial boundary layer tracer concentration at $335 \mathrm{~K}$. Pyroconvective mechanisms (deep convection triggered or enhanced by forest fires) were not parameterized in our simulation and were likely giving an extra contribution to deep intrusions into the stratosphere in that case, as reported by Damoah et al. (2006).

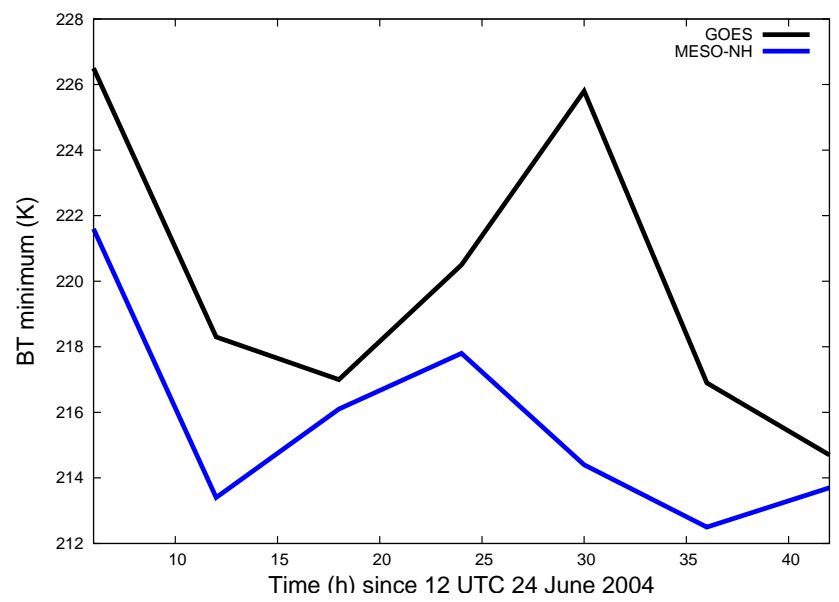

Fig. 11. Minimum temperature brightness during the model simulation $(\mathrm{K})$.

Further investigations are needed to better assess the importance of convection and synoptic-scale storm systems on the formation of a mixing zone above the tropopause (Hoor et al., 2002; Stohl et al., 2003; Brioude et al., 2008) and on the modification of stratospheric radiation balance and chemistry. MOZAIC observations presented here show that sharp gradients of trace gases and well defined anticorrelations between them were maintained even after 5-6 days of continental-scale transport and despite mixing effects such as stirring and diffusion processes in the lower stratosphere. The long lifetime of such fire plumes deep in the lowermost stratosphere suggests that their frequency of observation by a routine program such as MOZAIC (more than 28000 flights in the period 1994-2008) could be significant. Future work will include a statistical investigation of the MOZAIC data to assess how often fire plumes are observed in the lowermost stratosphere and how the pollutants evolve during their lifetime in the stratosphere.

\section{Appendix A}

\section{Products available from FLEXPART simulations}

The following description is extracted from the NOAA web page for the analysis of the ICARTT experiment, available at http://www.esrl.noaa.gov/csd/ICARTT/analysis/ description.html.

The column residence time shows the vertically integrated residence time of the particles. It always shows the entire retroplume and gives the quickest impression of where the air came from but without altitude information. Strictly, this is not a residence time, but the response an emission release of unit source strength would have at the receptor (i.e., at the measurement point) assuming no chemical transformations, 


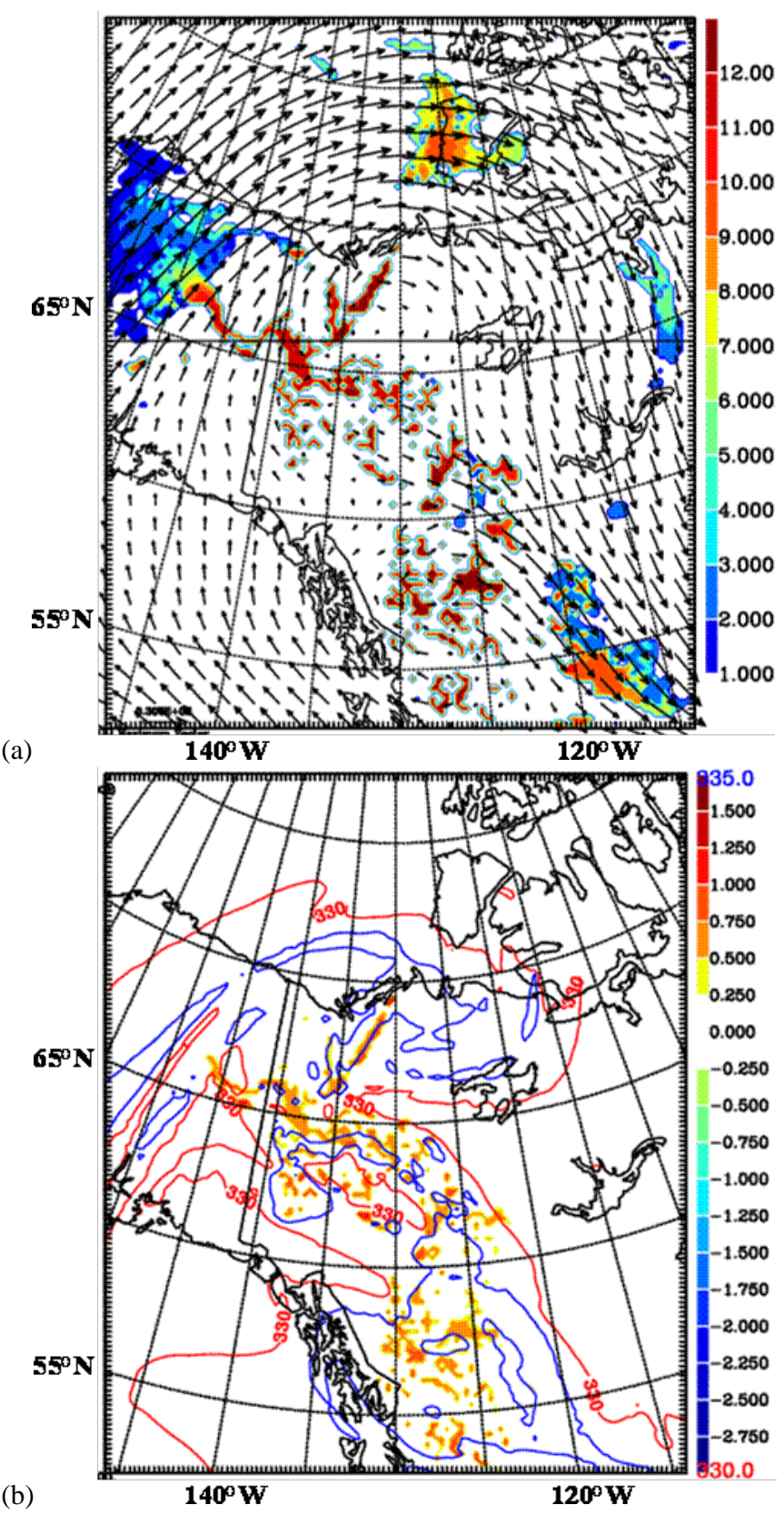

Fig. 12. Diagnoses of convection with Meso-NH on 25 June 2004, 00:00 UTC (17 h local time the day before). (a) Height of convective cloud tops $(\mathrm{km})$ and wind vectors at $12 \mathrm{~km}$ altitude. (b) Indicator of the characteristic time for convective mass fluxes to exchange air at the top of updraft (see text for details) projected on the dynamical tropopause ( 2 pvu surface) with potential temperature contours $330 \mathrm{~K}$ (red) and $335 \mathrm{~K}$ (blue).

deposition, etc. This response function is proportional to the residence time of all particles over a unit area (hence the name chosen), but involves scaling with the specific volume of air. The unit shown is nanoseconds times meters divided by kilograms.

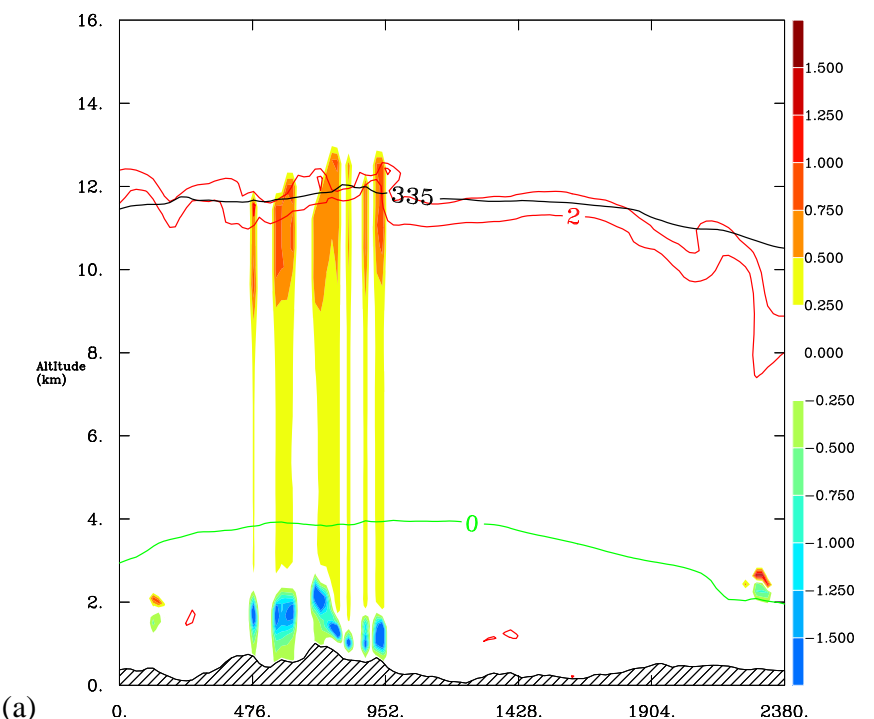

(a)

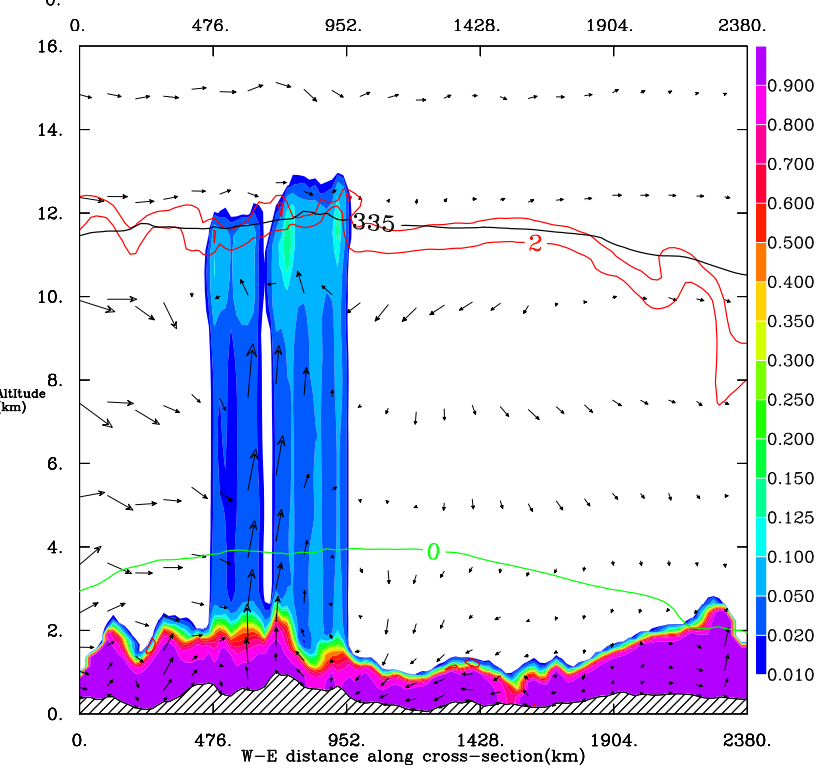

(b)

Fig. 13. Vertical cross section from Meso-NH on 25 June 2004, 00:00 UTC (17:00 h local time the day before), the location of the cross-section is shown on Fig. 12a. (a) Indicator of the characteristic time for convective mass fluxes to exchange air at the root and the top of updraft and downdraft (see text for details) with potential vorticity contours ( 2 and $5 \mathrm{pvu}$ ), isentropic surface $335 \mathrm{~K}$, and isothermal $0^{\circ} \mathrm{C}$. (b) Boundary layer tracer concentration (between 0 and 1).

The footprint residence time is the column residence time averaged over the lowest $150 \mathrm{~m}$ instead of vertically integrated. As anthropogenic emissions are mostly located at the surface, this gives an indication of where emissions were likely taken up. The unit shown is nanoseconds divided by kilograms.

The CO source contributions are products between the "residence time" and the anthropogenic emission flux (in kilograms per square meter and second) taken from the 


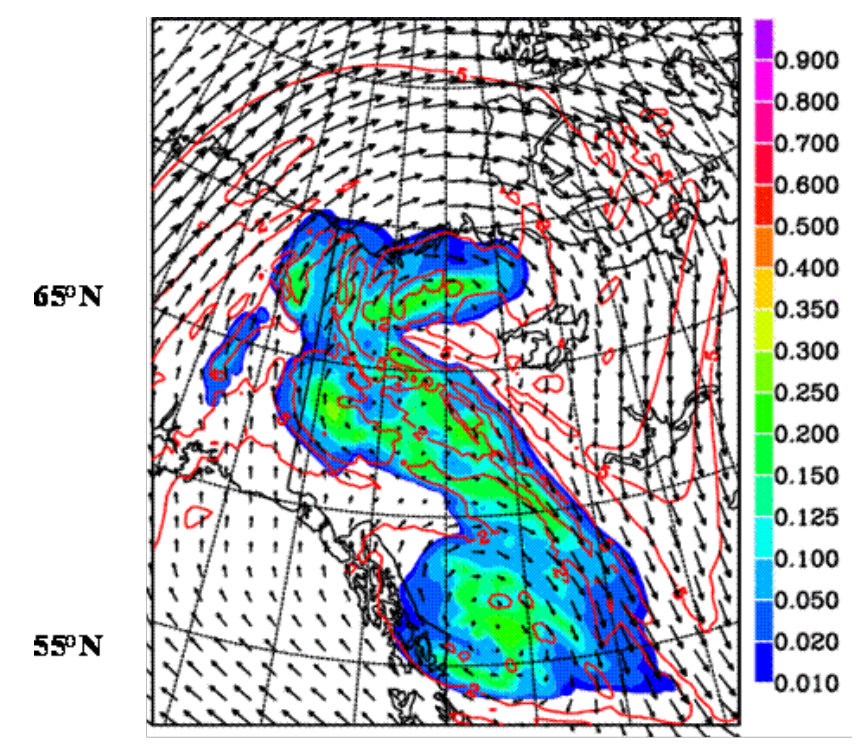

(a)

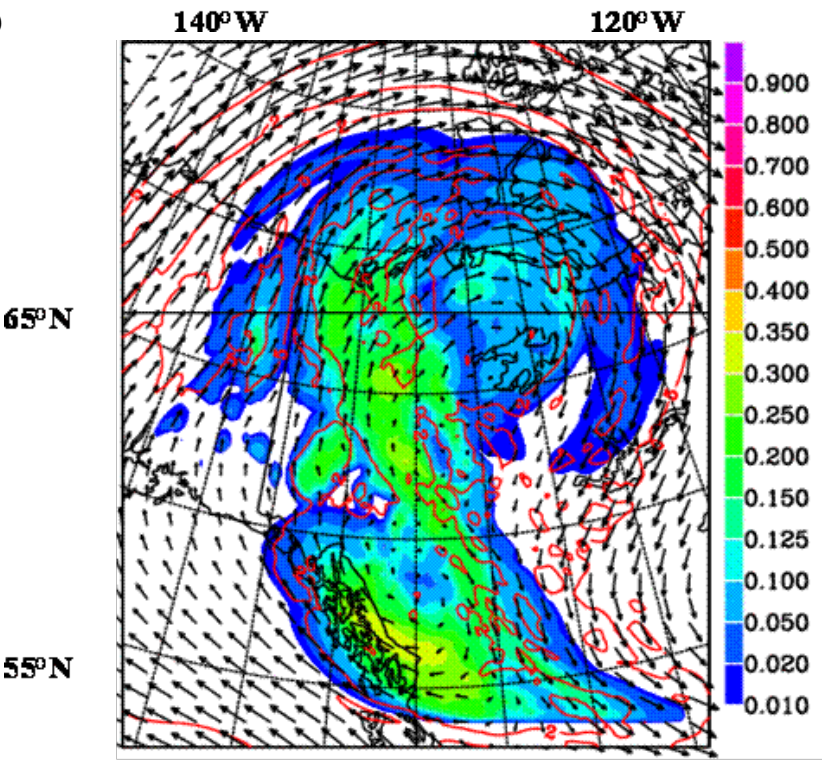

(b) $120^{\circ} \mathbf{W}$

Fig. 14. Boundary layer tracer concentration (between 0 and 1) due to convective detrainment fluxes on the isentropic surface $335 \mathrm{~K}$, wind arrows and potential vorticity isolines ( 2 and 5 pvu). Plots are for different ages of the boundary layer tracer: (a) 7-h age on 25 June 2004, 06:00 UTC (23:00 h local time the day before), (b) 25-h age on 26 June 2004, 00:00 UTC (17:00 h local time).

inventories. The result is an emission contribution in ppbv per square meter. If the emission contribution is integrated over the earth's surface, a "tracer" mixing ratio at the sampling location is obtained. It is also reported on the plot and, furthermore, Asian, American and European contributions are listed separately. These mixing ratios are quantitatively comparable to the measurements under the assumption that the species is conserved (no chemistry, no deposition).

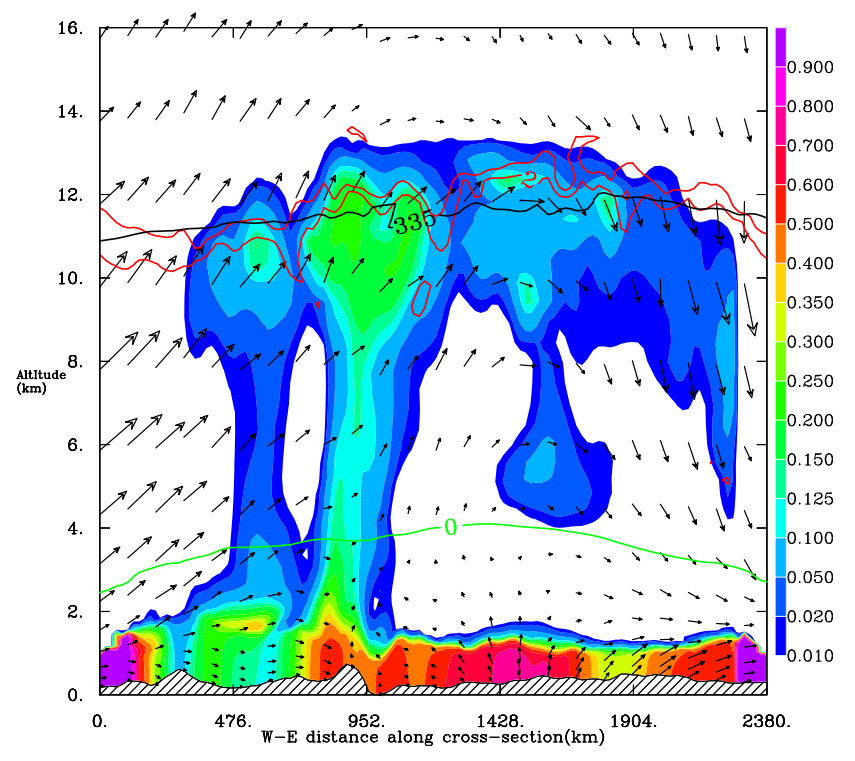

Fig. 15. Vertical cross-section on 26 June 00:00 UTC (17h local time) for the boundary layer tracer concentration (between 0 and 1). The location of the vertical section is shown on Fig. 14b. Red lines show the $2 \mathrm{pvu}$ and $5 \mathrm{pvu}$ isocontours, the black line is the $335 \mathrm{~K}$ isocontour and the green line is the $0^{\circ} \mathrm{C}$ isocontour. Vectors are horizontal winds projected into the plane of the cross-section,

CO source contributions from fires burning in North America are calculated, similarly to the anthropogenic pollution source contributions, using a self-made inventory of daily emissions from biomass burning in North America and assuming an injection height of 0-3000 $\mathrm{m}$ (i.e., a footprint of $3000 \mathrm{~m}$ ). The Center for International Disaster Information (http://iys.cidi.org/wildfire/) publishes daily burn areas, burnt per province in Canada and fire province in the United States The resulting timeseries were smoothed by a 3-day running mean. As a second source of information, MODIS hot spot data were obtained from theNOAA Satellite and Information Service. Hot spots were counted daily on a $1 \times 1$ degree grid and for every 3-day period the maximum daily number of hot spots was taken in order to account for possibly missing hot spots during cloudy periods. Then, the daily area burned in Alaska and the Canadian provinces was distributed to those grid cells in these provinces containing hot spots (weighted, according to the number of hot spots). The rest of the United States was treated as a single region instead of as different fire provinces. Sometimes, hot spots were detected when no area was given as burned in a province or vice versa. The missing area (about 10\%) was distributed equally-weighted to all hot spots detected during the entire period. Finally, a constant emission factor of $4500 \mathrm{~kg} \mathrm{CO}$ per hectare burned was used to obtain a daily $\mathrm{CO}$ emission inventory on a $1 \times 1$ degree grid. As the inventory involves some smoothing (both spatially and temporally) of the available fire information, 
peaks in fire contributions may be underestimated and a more spread-out "background" of fire contributions than observed may be simulated. Plots of emission tracer time series show the above tracers constructed from the backward simulations along the entire flight as time series, displayed separately for total anthropogenic, Asian, North American, and European pollution. Fires can sometimes inject emissions at very high altitudes. Time traces of the biomass burning $\mathrm{CO}$ contain a sensitivity analysis to the assumed injection height: below $150 \mathrm{~m}$, below $1000 \mathrm{~m}$, below $3000 \mathrm{~m}$, and below $10000 \mathrm{~m}$.

Acknowledgements. The authors acknowledge for their strong support the European Communities, EADS, Airbus and the airlines (Lufthansa, Austrian, Air France) who carry free of charge the MOZAIC equipment and perform the maintenance since 1994. MOZAIC is presently funded by INSU-CNRS (France), Meteo-France, and Forschungszentrum (FZJ, Julich, Germany). The MOZAIC data based is supported by ETHER (CNES and INSU-CNRS). We acknowledge E. Eloranta at the University of Wisconsin lidar group for providing lidar free-access images and O. Cooper (NOAA, Boulder, USA) for the set up of the web pages of the FLEXPART simulations for the ICARTT experiment. Computer resources for the Meso-NH simulations were allocated by IDRIS (projects 005, 569, and 1076). GOES-10 observations come from by SATMOS (CNRS/Meteo-France) and SAA (NOAA).

Edited by: A. Petzold

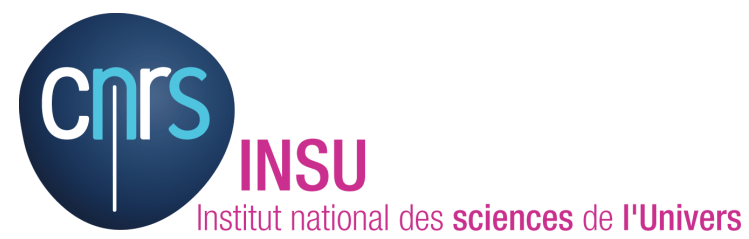

The publication of this article is financed by CNRS-INSU.

\section{References}

Bechtold, P., Bazile, E., Guichard, F., Mascart P. and Richard, E.: A Mass flux convection scheme for regional and global models. Q. J. Roy. Meteor. Soc., 127, 869-886, 2001.

Bertschi, I. T. and Jaffe, D. A.: Long-range transport of ozone, carbon monoxide, and aerosols to the NE Pacific troposphere during the summer of 2003: Observations of smoke plume from Asian boreal fires, J. Geophys. Res., 110, D05303, doi:10.1029/2004JD005135, 2005.

Bougeault, P. and Lacarrére, P.: Parameterization of orographic induced turbulence in a mesobetascale model, Mon. Weather Rev., 117, 1872-1890, 1989.

Brioude, J., Cammas, J.-P., Cooper, O. R., Nédélec, P.: Characterization of the composition, structure, and seasonal variation of the mixing layer above the extratropical tropopause as revealed by MOZAIC measurements, J. Geophys. Res., 113, D00B01, doi:10.1029/2007JD009184, 2008.

Chaboureau, J.-P., Cammas, J.-P., Mascart, P., Pinty, J.-P., Claud, C., Roca, R., and Morcrette, J.-J.: Evaluation of a cloud system life-cycle simulated by Meso-NH during FASTEX using METEOSAT radiances and TOVS-3I cloud retrievals, Q. J. Roy. Meteor. Soc., 126, 1735-1750, 2000.

Chaboureau, J.-P., Cammas, J.-P., Mascart, P., Pinty, J.-P., and Lafore, J.-P.: Mesoscale model cloud scheme assessment using satellite observations, J. Geophys. Res., 107(D16), 4301, doi:10.1029/2001JD000714, 2002.

Chaboureau, J.-P., and Pinty, J.-P.: Validation of a cirrus parameterization with Meteosat Second Generation observations, Geophys. Res. Lett., 33, L03815, doi:10.1029/2005GL024725, 2006.

Cofer, W. R.III, Winstead, E. L., Stocks, B. J., Goldammer, J. G., and Cahoon, D. R.: Crown fire emissions of $\mathrm{CO}_{2}, \mathrm{CO}, \mathrm{H}_{2}, \mathrm{CH}_{4}$, and TNMHC from a dense jack pine boreal forest fire, Geophys. Res. Lett., 25(21), 3919-3922, doi:10.1029/1998GL900042, 1998.

Cooper, O., Stohl, A., Eckhardt, S., Parrish, D. D., Oltmans, S. J., Johnson, B. J., Nédélec, P., Schmidlin, F. J., Newchurch, M. J., Kondo, Y., and Kazayuki, K.: A springtime comparison of tropospheric ozone and transport pathways on the east and west coasts of the United States. J. Geophys. Res. 110, D05S90, doi:10.1029/2004JD005183, 2005.

Crutzen, P. J. and Andreae, M. O.: Biomass burning in the tropics: Impact on atmospheric chemistry and biogeochemical cycles, Science, 250, 1669-1678, 1990.

Cuxart, J., Bougeault, P., and Redelsperger, J.-L.: A turbulence scheme allowing for mesoscale and large-eddy simulations, Q. J. Roy. Meteor. Soc., 126, 1-30, 2000

Damoah, R., Spichtinger, N., James, P., Servranckx, R., Fromm, M., Eloranta, E. W., Razenkov, I.A., James, P., Shulski, M., Forster, C., and Stohl, A.: A case study of pyro-convection using transport model and remote sensing data. Atmos. Chem. Phys., 6, 173-185, 2006, http://www.atmos-chem-phys.net/6/173/2006/.

Deardorff, J. W.: Three-dimensional numerical study of turbulence in an entraining mixed layer, Bound. Layer. Meteorol., 7, 199216, 1974.

Eloranta, E. W.: High Spectral Resolution Lidar in Lidar: RangeResolved Optical Remote Sensing of the Atmosphere, edited by: Weitkamp, K., Springer Series in Optical Sciences, Springer Verlag, New York, USA, 143-163, 2005.

Forster, C., Wandinger, U., Wotawa, G., James, P., Mattis, I., Althausen, D., Simmonds, P., ODoherty, S., Jennings, S. G., Kleefeld, C., Schneider, J., Trickl, T., Kreipl, S., Jäger, H., and Stohl, A.: Transport of boreal forest fire emissions from Canada to Europe, J. Geophys. Res., 106(D19), 22887-22906, 2001.

Fromm, M., Alfred, J., Hoppel, K., Hornstein, J., Bevilacka, R., Shettle, E., Servranckx, R., Li, Z., and Stocks, B.: Observation of boreal forest fire smoke in the stratosphere by POAM III, SAGE II, and lidar in 1998. Geophys. Res. Lett., 27, 1407-1410, 2000.

Fromm, M. D. and Servranckx, R.: Transport of forest fire smoke above the tropopause by supercell convection, Geophys. Res. Lett., 30(10), 1542, doi:10.1029/2002GL016820, 2003.

Fromm, M., Belavicqua, R., Servranckx, R., Rosen, J., Thayer, J. P., Herman, J. and Larko, D.: Pyro-cumulonimbus injection of smoke to the stratosphere: observations and impact of a super blowup in northwestern Canada on 3-4 August 1998, J. Geophys. Res, 110, D08205, doi:10.1029/2004JD005350, 2005.

Frost, G.J., McKeen, S. A., Trainer, M., Ryerson, T. B., Neuman, J. A., Roberts, J. M., Swanson, A., Holloway, J. S., Sueper, D. T., Fortin, T., Parrish, D. D., Fehsenfeld, F. C., Flocke, F., Peckham, 
S. E., Grell, G. A., Kowal, D., Cartwright, J., Auerbach, N., and Habermann, T.: Effects of changing power plant $\mathrm{NO}_{\mathrm{X}}$ emissions on ozone in the eastern United States: Proof of concept, J. Geophys. Res., 111, D12306, doi:10.1029/2005JD006354, 2006.

Goode, J. G., Yokelson, R. J., Ward, D. E., Susott, R. A., Babbitt, R. E., Davies, M. A., and Hao, W. M.: Measurements of excess $\mathrm{O}_{3}, \mathrm{CO}_{2}, \mathrm{CH}_{4}, \mathrm{C}_{2} \mathrm{H}_{4}, \mathrm{C}_{2} \mathrm{H}_{2}, \mathrm{HCN}, \mathrm{NO}, \mathrm{NH}_{3}$, $\mathrm{HCOOH}, \mathrm{CH}_{3} \mathrm{COOH}, \mathrm{HCHO}$, and $\mathrm{CH}_{3} \mathrm{H}$ in 1997 Alaskan biomass burning plumes by airborne Fourier transform infrared spectroscopy (AFTIR) $\left[\mathrm{O}_{3}, \mathrm{CO}_{2}, \mathrm{CH}_{4}, \mathrm{C}_{2} \mathrm{H}_{4}, \mathrm{C}_{2} \mathrm{H}_{2}, \mathrm{NH}_{3}\right.$, $\mathrm{CH}_{3} \mathrm{COOH}, \mathrm{CH}_{3} \mathrm{H}$ ], J. Geophys. Res., 105(D17), 2214722166, doi:10.1029/2000JD900287, 2000.

Gregory, D., Morcrette, J.-J., Jakob, C., Beljaars, A. M., and Stockdale, T.: Revision of convection, radiation and cloud schemes in the ECMWF model, Q. J. Roy. Meteor. Soc., 126, 1685-1710, 2000.

Helten M., Smit, H., Strater, W, Kley, D., Nédélec, P., Zoger, M., and Busen, R.: Calibration and performance of automatic compact instrumentation for the measurement of relative humidity from passenger aircraft, J. Geophys. Res., 103, 25643-25652, 1998.

Helten M., Smit, H.G.J., Kley, D., Ovarlez, J., Schlager, H., Baumann, R., Schumann, U., Nédélec, P., and Marenco, A.: In-Flight Intercomparison of MOZAIC and POLINAT Water Vapor Measurements, J. Geophys. Res., 104(D21), 26087-26096, 1999.

Hoor, P., Fischer, H., Lange, L., Lelieveld, J., and Brunner D.: Seasonal variations of a mixing layer in the lowermost stratosphere as identified by the $\mathrm{CO}-\mathrm{O}_{3}$ correlation from in situ measurements, J. Geophys. Res., 107(D5), 4044, doi:10.1029/2000JD000289, 2002.

Iacobellis, S., Frouin, R., and Somerville, R.: Direct climate forcing by biomass-burning aerosols: Impact of correlations between controlling variables, J. Geophys. Res., 104(D10), 12031-12045, 1999.

Jaffe, D. A., Bertschi, I., Jaeglé, L., Novelli, P., Reid, J. S., Tanimoto, H., Vingarzan, R. and Westphal, D.: Long-range transport of Siberian biomass burning emissions and impact on surface ozone in western North America, Geophys. Res. Lett., 31, L16106, doi:10.1029/2004GL020093, 2004.

Jost, H.-J., Drdla, K., Stohl, A., et al.: In-situ observations of midlatitude forest fire plumes deep in the stratosphere, Geophys. Res. Lett., 31, L11101, doi:10.1029/2003GL019253, 2004.

Lafore, J. P., Stein, J., Asencio, N., Bougeault, P., Ducrocq, V., Duron, J., Fischer, C., Hereil, P., Mascart, P., Pinty, J. P., Redelsperger, J. L., Richard, E. and Vila-Guerau de Arellano, J.: The Meso-NH Atmospheric Simulation System. Part I: Adiabatic formulation and control simulations, Ann. Geophys., 16, 90-109, 1998, http://www.ann-geophys.net/16/90/1998/.

Lavoué, D., Liousse, C., Cachier, H., Stocks, B. J., and Goldammer, J. G.: Modeling of carbonaceous particles emitted by boreal and temperate wildfires at northern latitudes, J. Geophys.Res., 105, 26871-26890, 2000.

Luderer, G., Trentmann,J., Winterrath, T., Textor,C., Herzog,M., Graf,H.F., and Andreae,M.O.: Modeling of biomass smoke injection into the lower stratosphere by a large forest fire (PartII): sensitivity studies, Atmos. Chem. Phys., 6, 5261-5277, 2006, http://www.atmos-chem-phys.net/6/5261/2006/.

Luderer,G., Trentmann,J., Hungershfer,K., Herzog,M., Fromm,M., and Andreae,M.O.: Small-scale mixing processes enhanc- ing troposphere-to-stratosphere transport by pyro-cumulonimbus storms, Atmos. Chem. Phys., 7, 5945-5957, 2007,

http://www.atmos-chem-phys.net/7/5945/2007/.

Marenco, A., Thouret, V., Nédélec, P., Smit, H., Helten, M., Kley, D., Karcher, F., Simon, P., Law, K., Pyle, J., Poschmann, G., Von Wrede, R., Hume C. and Cook T.: Measurement of ozone and water vapour by Airbus in-service aircraft: the MOZAIC airborne program, An overview, J. Geophys. Res., 103, 2563125642, 1998.

Mlawer, E. J., Taubman, S. J., Brown, P. D., Iacono, M. J., and Clough, S. A.: Radiative transfer for inhomogeneous atmospheres: RRTM, a validated corrolated-k model for the longwave, J. Geophys. Res., 102D, 16663-16682, 1997.

Murphy, D. M. and Fahey, D. W.: An estimate of the flux of stratospheric reactive nitrogen and ozone into the troposphere. J. Geophys. Res. 99, 5325-5332, 1994.

Nédélec, P., Cammas, J. P., Thouret V., Athier, G., Cousin, J. M., Legrand, C., Abonnel, C., Lecoeur, F., Cayez, G. and Marizy, C.: An improved infra-red carbon monoxide analyser for routine measurements aboard commercial Airbus aircraft: Technical validation and first scientific results of the MOZAIC program, Atmos. Chem. Phys., 3, 1551-1564, 2003,

http://www.atmos-chem-phys.net/3/1551/2003/.

Nédélec P., Thouret, V., Brioude, J., Sauvage, B., Cammas, J.P., and Stohl A.: Extreme $\mathrm{CO}$ concentrations in the upper troposphere over North-East Asia in June 2003 from the insitu MOZAIC aircraft data, Geophys. Res. Lett., 32, L14807, doi:10.1029/2005GL023141, 2005.

Olivier, J. G. J. and Berdowski J. J. M.: Global emissions sources and sinks, in: The Climate System, edited by: Berdowski, J., Guicherit, R., and Heij, B. J., 33-78, A.A. Balkema Publishers/Swets Zeitlinger Publishers, Lisse, The Netherlands, ISBN 90-5809-255-0, 2001.

Pätz,H.-W., Volz-Thomas,A., Hegglin,M.I., Brunner,D., Fischer,H., and Schmidt,U.: In-situ comparison of the $\mathrm{NO}_{\mathrm{y}}$ instruments flown in MOZAIC and SPURT, Atmos. Chem. Phys., 6, 24012410, 2006, http://www.atmos-chem-phys.net/6/2401/2006/.

Petzold,A., Weinzierl,B., Huntrieser,H., Stohl,A., Real,E., Cozic, J., Fiebig,M., Hendricks,J., Lauer,A., Law,K., Roiger,A., Schlager, H., and Weingartner,E.: Perturbation of the European free troposphere aerosol by North American forest fire plumes during the ICARTT-ITOP experiment in summer 2004, Atmos. Chem. Phys., 7, 5105-5127, 2007,

http://www.atmos-chem-phys.net/7/5105/2007/.

Pfister G. G., Emmons, L. K., Hess, P. G., Honrath, R., Lamarque, J.-F., Val Martin, M., Owen, R. C., Avery, M. A., Browell, E. V., Holloway, J. S., Nédélec, P., Purvis, R., Ryerson, T. B., Sachse, G. W., and Schlager, H., Ozone production from the 2004 North American boreal fires, J. Geophys. Res., 111, D24S07, doi:10.1029/2006JD007695, 2006.

Pinty, J.-P. and Jabouille, P.: A mixed-phase cloud parameterization for use in a mesoscale non-hydrostatic model: simulations of a squall line and of orographic precipitations, in: Proc. AMS conference on cloud physics, 17-21 August 1998, Everett, WA, USA, 217-220, 1998.

Real, E., Law, K. S., Weinzierl, B., Fiebig, M., Petzold, A., Wild, O., Methven, J., Arnold, S., Stohl, A., Huntreiser, H., Roiger, A., Schlager, H., Stewart, D., Avery, M., Sachse, G., Browell, E., Ferrare, R., and Blake, D., Processes influencing ozone 
levels in Alaskan forest fire plumes during long-range transport over the North Atlantic, J. Geophys. Res., 112, D10S41, doi:10.1029/2006JD007576, 2007.

Real, E., Law, K. S., Schlager, H., Roiger, A., Huntrieser, H., Methven, J., Cain, M., Holloway, J., Neuman, J. A., Ryerson T., Flocke, F., de Gouw, J., Atlas, E., Donnelly, S., and Parrish, D., Lagrangian analysis of low altitude anthropogenic plume processing across the North Atlantic, Atmos. Chem. Phys., 8, 77377754, 2008, http://www.atmos-chem-phys.net/8/7737/2008/.

Robock, A.: Surface Cooling Due to Forest Fire Smoke, J. Geophys. Res., 96(D11), 20869-20878, 1991.

Saunders, R., Matricardi, M., Brunel, P., English, S., Bauer, P., OKeeffe, U., Francis, P., and Rayer, P.: RTTOV-8 Science and validation report, Tech. rep., NWP SAF Report, 41 pp., 2005.

Seibert, P. and Frank, A.: Source-receptor matrix calculation with a Lagrangian particle dispersion model in backward mode, Atmos. Chem. Phys. 4, 51-63, 2004.

Spichtinger, N., Wenig, M., James, P., Wagner, T., Platt, U., and Stohl, A.: Satellite detection of a continental-scale plume of nitrogen oxides from boreal forest fires, Geophys. Res. Lett., 28, 4579-4582, 2001.

Stohl, A., Spichtinger-Rakowsky, N., Bonasoni, P., Feldmann, H., Memmesheimer, M., Scheel, H. E., Trickl, T., Hübener, S. H., Ringer, W., and Mandl, M.: The influence of stratospheric intrusions on alpine ozone concentrations, Atmos. Environ., 34, 1323-1354, 2000.

Stohl, A., Forster, C., Eckhardt, S., et al.: A backward modeling study of intercontinental pollution transport using aircraft measurements, J. Geophys. Res., 108, 4370, doi:10.1029/2002JD002862, 2003.

Stohl, A., Bonasoni, P., Christofanelli, P., et al.: Stratospheretroposphere exchange: A review, and what we have learned from STACCATO, J. Geophys. Res., 108(D12), 8516, doi:10.1029/2002JD002490, 2003.
Stohl, A., Forster, C., Frank, A., Seibert, P., and Wotawa, G.: Technical note: The Lagrangian particle dispersion model FLEXPART version 6.2., Atmos. Chem. Phys., 5, 2461-2474, 2005, http://www.atmos-chem-phys.net/5/2461/2005/.

Thouret, V., Marenco, A., Logan, J. A., Nédélec, P., and Grouhel, C.: Comparisons of ozone measurements from the MOZAIC airborne program and the ozone sounding network at eight locations, J. Geophys. Res., 103, 25695-25720, 1998.

Trentmann,J., Luderer,G., Winterrath,T., Fromm,M.D., Servranckx,R., Textor,C., Herzog,M., Graf,H.-F., and Andreae,M.O.: Modeling of biomass smoke injection into the lower stratosphere by a large forest fire (Part I): reference simulation, Atmos. Chem. Phys., 6, 5247-5260, 2006, http://www.atmos-chem-phys.net/6/5247/2006/.

van der Werf, G. R., Randerson, J. T., Giglio, L., Collatz, G. J., Kasibhatla, P. S., and Arellano Jr., A. F.: Interannual variability in global biomass burning emissions from 1997 to 2004, Atmos. Chem. Phys., 6, 3423-3441, 2006, http://www.atmos-chem-phys.net/6/3423/2006/.

Volz-Thomas A., Berg, M., Heil, T., Houben, N., Lerner, A., Petrick, W., Raak, D., and Pätz, H.-W.: Measurements of total odd nitrogen $\left(\mathrm{NO}_{\mathrm{y}}\right)$ aboard MOZAIC in-service aircraft: instrument design, operation and performance, Atmos. Chem. Phys., 5, 583595, 2005, http://www.atmos-chem-phys.net/5/583/2005/.

Waibel, A. E., Fisher, H., Wienhold, F. G., Siegmund, P. C., Lee, B., Ström, J., Lelieveld, L., and Crutzen, P. J.: Highly elevated carbon monoxide concentrations in the upper troposphere and lowermost stratosphere at northern midlatitudes during the STREAM II summer campaign in 1994, Chemosphere, 1(1-3), 233-248, 1999.

Wotawa G. and Trainer, M.: The influence of Canadian forest fires on pollutant concentrations in the United States, Science, 288, 324-328, 2000. 